\title{
Family Firms
}

\section{Citation}

Burkart, Mike, Fausto Panunzi, and Andrei Shleifer. 2003. Family Firms. The Journal of Finance 58, no. 5: 2167-2201. Portico. doi:10.1111/1540-6261.00601.

\section{Published Version}

doi:10.1111/1540-6261.00601

\section{Permanent link}

http://nrs.harvard.edu/urn-3:HUL.InstRepos:30747196

\section{Terms of Use}

This article was downloaded from Harvard University's DASH repository, and is made available under the terms and conditions applicable to Other Posted Material, as set forth at http:// nrs.harvard.edu/urn-3:HUL.InstRepos:dash.current.terms-of-use\#LAA

\section{Share Your Story}

The Harvard community has made this article openly available.

Please share how this access benefits you. Submit a story.

Accessibility 
Fondazione Eni Enrico Mattei

\title{
Family Firms
}

\author{
Mike Burkart, Fausto Panunzi \\ and Andrei Shleifer
}

NOTA DI LAVORO 74.2002

SEPTEMBER 2002

PRIV - Privatisation, Regulation, Antitrust

Mike Burkart, Stockholm School of Economics, Sweden and CEPR

Fausto Panunzi, Università di Bologna, Italy and CEPR

Andrei Shleifer, Harvard University, USA and NBER

This paper can be downloaded without charge at:

The Fondazione Eni Enrico Mattei Note di Lavoro Series Index:

http://www.feem.it/web/activ/_activ.html

Social Science Research Network Electronic Paper Collection: http://papers.ssrn.com/abstract_id=XXXXXX

The opinions expressed in this paper do not necessarily reflect the position of Fondazione Eni Enrico Mattei 


\section{Family Firms}

\section{Summary}

We present a model of succession in a firm owned and managed by its founder. The founder decides between hiring a professional manager or leaving management to his heir, as well as on how much, if any, of the shares to float on the stock exchange. We assume that a professional is a better manager than the heir, and describe how the founder's decision is shaped by the legal environment. Specifically, we show that, in legal regimes that successfully limit the expropriation of minority shareholders, the widely held professionally managed corporation emerges as the equilibrium outcome. In legal regimes with intermediate protection, management is delegated to a professional, but the family stays on as large shareholders to monitor the manager. In legal regimes with the weakest protection, the founder designates his heir to manage and ownership remains inside the family. This theory of separation of ownership from management includes the Anglo-Saxon and the Continental European patterns of corporate governance as special cases, and generates additional empirical predictions consistent with cross-country evidence.

Keywords: Family firms, legal protection, corporate governance

JEL: G32

The authors are grateful to Mara Faccio, Julian Franks, Rob Gertner, Denis Gromb, Simon Johnson, Rafael La Porta, Enrico Perotti, Jeremy Stein, Daniel Wolfenzon, the editor, an anonymous referee, and seminar participants at Bologna, INSEAD, London Business School, the NBER Corporate Finance Conference (Chicago), Padua, Salerno, Stockholm School of Economics, Venice and Zurich for helpful comments and discussions. Financial support from Università Bocconi (Ricerca di Base), from the Bank of Sweden Tercentenary Foundation, and from the Gildor Foundation is gratefully acknowledged. Robin Greenwood provided excellent research assistance. This paper is produced as part of a CEPR project on Understanding Financial Architecture: Legal Framework, Political Environment and Economic Efficiency, funded by the European Commission under the Human Potential - Research Training Network program (Contract No. HPRN-CT-2000-00064).

Address for correspondence:

Fausto Panunzi

Università di Bologna

Piazza Scaravilli, 2

40126 Bologna

E-mail: fpanunzi@economia.unibo.it 


\section{Introduction}

Most firms in the world are controlled by their founders, or by the founders' families and heirs. Such family ownership is nearly universal among privately held firms, but also dominant among publicly traded firms. In Western Europe, South and East Asia, Middle East, Latin America, and Africa, the vast majority of publicly traded firms are family controlled (La Porta et al. 1999, Claessens et al. 2000, European Corporate Governance Network 2001, Faccio and Lang 2002). But even in the United States and the U.K., some of the largest publicly traded firms, such as Wal-Mart Stores and Ford Motor, are controlled by families.

A crucial issue in the discussion of family firms from the perspective of corporate governance and finance is succession. For nearly every entrepreneurial firm that does not fail, there comes a moment when the founder no longer wishes to manage it. This can happen from the very beginning, when founders seek professional managers to run their firms, as is the case in high technology startups in the United States. Alternatively, a founder can retire or cut his work load later in life, and appoint either a heir or a professional as a successor. When control is turned over to a professional, ownership and management become separated.

The patterns of separation of ownership and management vary across countries. In the United States, founders often hire professional managers early on. By the time a founder retires, his family retains only marginal ownership. In such Berle and Means (1932) corporations, professional managers exercise nearly full control. In Western Europe, significant ownership typically stays with the family after the founder retires. His children either hire a manager, as in BMW or FIAT, or run the firm themselves, as in Peugeot. In emerging markets, both management and ownership tend to stay with the family when the founder retires. Occasionally in both developed and emerging markets, a manager marries into the family, as happened at 
Bombardier in Canada, Matshushita in Japan, and Worldwide Shipping in Hong Kong.

There are three broad theories of the preservation of family control. According to the first, there is a significant "amenity potential" of family control. We use the term "amenity potential," suggested by Demsetz and Lehn (1985), to refer to non-pecuniary private benefits of control, meaning utility to the founder that does not come at the expense of profits. A founder may derive pleasure from having his child run the company that bears the family name. Alternatively, in some industries, such as sports or the media, a family can participate in, or even influence, exciting social, political, and cultural events through ownership of firms. This reason for family control suggests that there will be a distribution of ownership patterns within a country, with companies delivering a large amenity potential of control staying in family hands.

If the amenity potential is large, we expect families to try to maintain control as long as they can. Only if a firm desperately needs capital and cannot raise it without a control change, or if the founder dies and significant inheritance taxes are due, will control be sold off. Some recent research indeed points to the importance of these considerations. In a cross-section of 20 countries, Wells (1998) finds a higher incidence of widely-held, as opposed to family-controlled, firms in countries with higher inheritance taxes. Bhattacharya and Ravikumar $(2001,2002)$ present theoretical models linking the persistence of family control to imperfect capital markets. In our model, we recognize the role of the amenity potential in keeping some firms under family control. But we use a framework that simultaneously explains capital market underdevelopment and the prevalence of family ownership based on institutional characteristics of a country.

A second reason for the preservation of family control is that the name itself may be a carrier of a reputation, in both economic and political markets. Families may stand for quality (as advertisements often argue), or for political connections. Italy's Agnellis have stayed close 
to the government, sometimes having family members in the cabinet, and always securing public transfers to Fiat. Such "reputational benefits" would be diluted if control is surrendered to an outsider. This theory suggests, counter-factually, that ceteris paribus family-controlled firms would be more valuable than firms controlled by professionals. Although it deserves a closer analysis, we do not consider the connection between family control and politics in this paper.

We focus on a third theory of family ownership, namely the possibility of expropriation of outside investors that comes with control. Unlike the amenity potential, such private benefits of control, described by Jensen and Meckling (1976) and Grossman and Hart (1988), do come at the expense of profits accruing to the outside investors. In our theory, the principal benefit of hiring a professional is that he is likely to be a better manager. The principal cost is that now the professional manager, rather than the founder, controls the company and so can expropriate investors. We argue that a crucial factor shaping the attractiveness of delegated management is the degree of legal protection of outside shareholders from expropriation (or tunneling) by the insiders. Earlier research shows that such protection varies sharply across countries, and that this variation predicts the differences in financial development and ownership structures (La Porta et al. 1997, 1998, 2000a,b, Johnson et al. 2000). In this paper, we examine the costs and benefits of delegating management from this perspective. This allows us, in particular, to examine the costs and benefits of keeping the succession of management inside the family.

We present a model of a founder looking for a manager to succeed him. We assume that there is no superior manager available with sufficient resources to buy the firm outright. When such a manager (or a company) is available, the firm is simply sold to them - as often happens. Absent an outright buyer, the founder chooses among three options. He can sell out completely in the stock market and create a widely held firm run by a professional manager. He can hire a 
professional manager but stay on as a large shareholder to monitor him. He can also keep the firm inside the family by either staying on as a less than ideal manager or passing management to a family member, who is generally not as talented as a professional. The founder maximizes his welfare, which is equal to the sum of the value of the retained block, the revenues from selling shares to investors, and the amenity potential obtained only if the family keeps control.

We study the trade-off between superior management by the professional outsider and his discretion to expropriate shareholders. If the founder stays on as a large shareholder and monitors, he can control expropriation to some extent. In our framework, both the law and the monitoring reduce managerial expropriation. We show that when the family's amenity potential from managing the firm is very large, ownership and management are never separated. In contrast, management and ownership are always separated when the discrepancy in the managerial abilities of the professional and the founder (or heir) is very large and the amenity potential is small. Except for these extremes, the decision to keep control in the family depends on the quality of legal protection.

When legal protection of outside investors is very good, there is no need for monitoring in equilibrium, and the best arrangement is a widely held professionally-managed firm. When legal protection of outside investors is moderate, the benefits of professional managers are still high enough for the entrepreneur to surrender control, but it pays for him or his family to remain as large shareholders and monitor the manager. Finally, with sufficiently weak shareholder protection, the founder's ability to control expropriation is too limited, and management stays with his family even when someone else can run the firm better. In general, this analysis leads to a prediction of a negative relationship between investor protection and ownership concentration, consistent with a range of empirical evidence. 
We consider two versions of the model, one in which the founder - when he detects expropriation - forces the manager to stop it and pay dividends, and another in which he and the manager just share the spoils. In the first version, as in Shleifer and Vishny (1986), the founder provides a public good to the minority shareholders by monitoring the manager. In the second version, monitoring is no longer a public good, the benefits of which are shared by all shareholders. In fact, the only effect of monitoring is to raise the founder's share of the loot. The basic results we describe hold in both specifications, but the second version also yields the empirically accurate prediction of a positive premium paid for a controlling block of shares.

At a theoretical level, the model combines in one unified framework the twin conflicts essential to understanding corporate governance: that between the manager and the outside shareholders, and that between the large shareholder and the minority shareholders. By doing so, the model sheds light on the different prevalent patterns of ownership and management among countries. It shows, for example, why Anglo-Saxon patterns of corporate governance, with widely-held firms and traditional conflicts between professional managers and dispersed shareholders (Berle and Means 1932), are likely to be a feature of countries with very good legal protection of minority shareholders. It explains why "family" firms, in which the founder's family is a significant shareholder, or even the manager, over several generations are such an enduring phenomenon in countries with less effective legal protection of shareholders (La Porta et al. 1999, Claessens et al. 2000). Indeed, it explains how, in such countries, the twin conflicts between the manager and the large shareholder and between the two of them combined and the minority shareholders, coexist. The model is moreover consistent with the growing body of evidence that family management is generally inferior to professional management (Morck et al. 2000, Perez-Gonzales 2001). The basic trade-off between the benefits of delegated management, 
and the costs of giving up control - especially when legal protection is poor - appears consistent with a great deal of data.

Our paper joins a growing theoretical literature on corporate governance in the regimes of poor investor protection. Bebchuk (1999) shows that poor legal protection renders dispersed ownership structure unstable, because it allows extraction of significant private benefits. La Porta et al. (2002) and Himmelberg et al. (2001) study theoretically and empirically the determination of ownership structure when firms raise funds to finance investment. Burkart and Panunzi (2001) and Shleifer and Wolfenzon (2002) analyze the impact of legal shareholder protection on the optimal ownership structure. Shleifer and Wolfenzon (2002) consider ownermanagers and examine the relationship between legal protection and inside equity. Burkart and Panunzi (2001) assume that the professional manager and the large shareholder are distinct parties and analyze the relationship between the law and outside ownership concentration. By making the separation of ownership and management a choice variable, the present model extends and generalizes these two papers.

The paper is organized as follows. Section 2 outlines the model. Section 3 examines the founder's decision to hire a professional manager and to float shares when he cannot share private benefits. Section 4 analyses the case with collusion between founder and professional manager and derives implications for share value, block premium, and agency costs of separating ownership and management. Section 5 concludes. Mathematical proofs are in the appendix.

\section{The model}

Figure 1 presents the model's timeline. We consider a firm initially fully owned by its founder. At date 0 , the founder decides whether to appoint a professional manager to run the firm 
or keep management in the family. Simultaneously, he decides what fraction 1- $\alpha$ of the shares to sell to dispersed shareholders. The family keeps the remaining fraction $\alpha$. All shareholders are risk-neutral. If management stays in the family, there is no separation of ownership and management. If the founder appoints a professional manager, ownership and management are separated. In this case, the founder may also offer a wage and the professional manager accepts or rejects the offer to run the company at date 1 .

\section{Figure 1}

\begin{tabular}{|c|c|c|c|}
\hline 0 & 1 & 2 & 3 \\
\hline $\begin{array}{l}\text { Founder chooses the } \\
\text { manager, sells } \\
1-\alpha \text { shares, offers } \\
\text { professional manager } \\
\text { wage } w v_{M}\end{array}$ & $\begin{array}{l}\text { Managers' job } \\
\text { acceptance } \\
\text { decision }\end{array}$ & $\begin{array}{l}\text { Founder chooses } \\
\text { monitoring intensity } m\end{array}$ & $\begin{array}{l}\text { Decision on } \\
\text { dividends and } \\
\text { private benefits. } \\
\text { Payoffs are } \\
\text { realized }\end{array}$ \\
\hline
\end{tabular}

At date 3, the firm generates revenues that depend on the identity of the manager. If control remains inside the family, total revenues generated are $v_{F}$. In addition, the amenity potential $B$ accrues to the founder. $B$ may differ across founders and industries, but it does not reduce revenues $v_{F}$. If a professional manager runs the firm, total revenues are $v_{M}$. The professional manager may also enjoy some amenity potential from running the firm. He also has an outside option. To economize on notation, let $c$ denote the professional manager's utility when pursuing his outside option net of the foregone amenity potential. For simplicity, the outside option of the founder or the family is normalized to zero.

Assumption 1: $v_{M}-c>v_{F}$. 
There are two interpretations of the model. Under the first, the choice is between the founder himself, who is becoming outdated or reluctant to manage, and a professional outsider. Under the second, the founder definitely retires from management, and chooses as his successor either a professional manager or his heir. In both interpretations, retaining management inside the family reduces the profitability of the firm relative to hiring a professional.

Assumption 1 is consistent with a recent study by Morck, Stangeland, and Yeung (2000) of corporate control of Canadian firms. They find that heir-controlled firms have lower returns on sales and assets than comparable firms. Furthermore, firms with founder control have earnings that are lower than those of widely held firms but higher than those in heir-controlled firms. Perez-Gonzales (2001) provides evidence on firm performance following inherited control by studying 162 family transitions in the United States. In $38 \%$ of these cases, family members inherit the CEO position. These family CEOs are promoted to the post an average of 9 years earlier than professional managers and are detrimental to firm performance- the return on assets falls by $16 \%$ within two years of transition and $25 \%$ compared with unrelated CEOs.

In this model, if the founder is the best manager himself, there is no reason for him ever to sell equity. He stays on as the manager, keeps $100 \%$ of the firm, and there are no agency problems or conflicts. This assumption distinguishes the model from the papers of La Porta et al. (2002), Shleifer and Wolfenzon (2002), and Himmelberg et al. (2001), where equity is raised to finance investment projects, and therefore the size of the firm is endogenous.

The problems arise when the founder is no longer the best manager. He must then choose between hiring a more qualified outsider to manage, or alternatively staying on or (equivalently) naming a mediocre son as a successor. Importantly, we assume that the competent professional outsider has neither the resources nor the external funds to just buy the firm himself. 
As we show below, the outsiders' inability to raise external funds is consistent with the assumptions of the model, since to buy the firm, he has to pay for the private benefits accruing to the founder, which he cannot pledge to investors. Unless the superior manager is himself rich, he has to work for the family. Hiring a professional separates ownership from management.

At date 2, shareholders can monitor the professional manager and thereby deprive him of at least some private benefits. The monitoring technology is discussed below.

At date 3 , the revenues can either be paid out to all shareholders proportionally to their ownership stakes or diverted to generate private benefits $\Phi$. In countries with weakest shareholder protection, such private benefits take the form of outright theft. More commonly, they take the form of transactions with related parties, expropriation of corporate opportunities, transfer pricing, excessive salaries and perquisites, and so on (see Johnson et al. 2000).

Whoever manages the firm chooses the level of expropriation, subject to being monitored and partially impeded by the law. The non-contractible expropriation decision is modeled as the choice of $\phi \in[0,1]$, such that security benefits (dividends) are $(1-\phi) v_{i}$, and private benefits are $\Phi=\phi v_{i}, i=M, F$. Expropriation of shareholders is limited by the law. To model legal shareholder protection, we assume that the law sets an upper bound $\bar{\phi} \in[0,1]$ on the fraction of revenues that can be (at no cost) diverted by the party in control. ${ }^{1}$ Stronger legal protection corresponds to lower values of $\bar{\phi}$.

The law is not the only determinant of the fraction of resources diverted for private benefits. The other is monitoring, which occurs when a professional manager is hired. Although

\footnotetext{
${ }^{1}$ The amount $\bar{\phi} v_{i}$ is the legal upper bound that can be extracted as private benefits of control, irrespective of the form in which those benefits are enjoyed. In particular, wages in excess of market value are already incorporated in $\bar{\phi} v_{i}$.
} 
in principle all shareholders can monitor the manager, the free-rider problem prevents small shareholders from choosing to incur the cost. In equilibrium only the large shareholder monitors to reduce the fraction of resources appropriated by the manager. ${ }^{2}$ Recall that the legal upper bound on private benefits of control is $\bar{\phi} v_{M}$. Following Pagano and Röell (1998), we assume that the large shareholder can at a cost $k \frac{m^{2}}{2}$ reduce private benefit extraction by $m v_{M}$ where $m \in[0,1]$ and $k>0 .{ }^{3}$

The private benefits $\Phi$ differ from the amenity potential $B$ in two respects: they come at the expense of security benefits and their size depends on the legal shareholder protection and (in the absence of collusion) on the monitoring intensity.

Private monitoring and the law are alternative mechanisms for reducing expropriation of shareholders. When $k$ is strictly positive, monitoring is costly for the founder whereas reliance on the law is free. The public benefits of the law may not be free from the viewpoint of society, but they are to the founder. The interaction between these two mechanisms of policing the manager shapes the equilibrium governance structure.

Importantly, we assume that corporate and other law governing investor protection matters, and that firms cannot opt into more protective legal regimes via a contract, such as cross-listing or a better corporate charter. This assumption is consistent with the evidence that legal rules governing investor protection in different countries have significant consequences for

\footnotetext{
${ }^{2}$ We assume that there is no reason for the founder to sell his shares to another large shareholder who would monitor, since, if anything, the founder would have a comparative advantage at monitoring because of his knowledge.

${ }^{3}$ The cost parameter $k$ could also be considered a measure of legal shareholder protection. As will become clear below, modeling the differences in legal shareholder protection by varying the efficiency of the monitoring technology or by changing the upper bound on diversion is equivalent when the founder and the small shareholders have congruent interests. With collusion between the founder and the professional manager (section IV), this equivalence breaks down because monitoring protects the founder but not the shareholders from managerial expropriation.
} 
financial development (La Porta et al. 1997, 1998, 2000b). This assumption is also consistent with recent theory and evidence pointing to the limited usefulness of such contractual solutions (Nenova 2001, Siegel 2002). If a founder could opt into a more protective legal regime before selling any shares, he would do so since in equilibrium he bears the monitoring cost of reducing managerial expropriation.

If a professional manager is hired, the question arises whether a monitoring founder can enjoy (part of) the private benefits. We consider both the cases of collusion and no collusion between the professional manager and the founder. Excluding the founder from the spoils of extraction is tantamount to assuming that his interests and those of the small shareholders are perfectly congruent. This case is most appropriate when the legal duties of the large shareholder, perhaps as a board member, bar him from complicity with the manager in expropriating shareholders. In contrast, when the founder and the professional manager can share the private benefits, they may collude at the expense of minority shareholders. This assumption might be more suitable for weaker legal regimes. The second assumption complicates the model, in that rent-seeking monitoring, intended to capture some of the private benefits rather than serve all shareholders, becomes attractive. We solve the model under the first assumption in the next section, and under the second in section IV.

\section{Owner-Manager or Professional Manager}

We analyze the founder's decision whether to hire a professional manager in steps. We begin by considering the founder's maximization problem for the cases of non-separation and separation of ownership and management. In each case, we solve the model by backward induction, going from the date 3 expropriation decision, to the founder's date 2 monitoring 
intensity, to the manager's date 1 job acceptance choice. We then can determine the optimal number of shares that the founder retains in cases of separation and non-separation. Having done that, we can compare the entrepreneur's welfare for different legal environments, i.e., different values of $\bar{\phi}$, which enables us to infer under what circumstances he chooses to separate ownership from management.

\section{A) No Separation of Ownership and Management}

Due to the simplicity of the model, the case of no separation does not yield precise predictions, notably for the ownership structure. At date 3 the founder decides how to allocate the revenues. While the law does not influence the amenity potential $B$, it constrains the founder to divert no more than $\bar{\phi} v$ of the revenues as private benefits $\Phi$. Unless he owns all the shares, in which case he is indifferent between any $\phi \in[0, \bar{\phi}]$, he extracts the legal upper bound $\bar{\phi}$. Absent a professional manager, there is neither date 2 monitoring nor a date 1 job acceptance decision. Hence, we move directly to the founder's date 0 decision as to which fraction of shares to sell to outside investors. The founder maximizes his welfare $V^{N S}$, which is the sum of three terms: the value of his date 3 block, $\alpha(1-\bar{\phi}) v_{F}+\bar{\phi} v_{F}$; the proceeds from selling $1-\alpha$ shares at date $0 ;(1-\alpha)(1-\bar{\phi})$, and the amenity potential $B$. Since diversion is efficient and since the founder is by assumption neither financially constrained nor risk averse, the optimal ownership structure is indeterminate when ownership and management are separated.

Lemma 1: For any $\bar{\phi} \in[0,1], V^{N S}\left(\alpha^{*}\right)=v_{F}+B$ and $\alpha^{*} \in[0,1]$.

The founder's welfare is equal to the total revenues under his management plus the 
amenity potential of managing the company. Even though private benefit extraction decreases with the quality of the law, the founder's welfare is independent of the legal environment. Since the extraction of private benefits is efficient, each diverted dollar reduces the security benefits by a dollar. Diversion reduces the price at which the founder can sell shares to investors, but increases the value of his block by an identical amount. The sum of security and private benefits (including both the amenity potential $B$ and private benefits $\Phi$ ) is constant.

\section{B) Separation of ownership and management}

What happens when ownership and management are separated? The founder gives up the amenity potential $B$ and also transfers to the professional manager the opportunity to divert corporate revenues as private benefits rather than pay them out as dividends to the shareholders. While the law constrains diversion, the founder can further limit private benefit extraction through monitoring. Monitoring may also induce opportunistic behavior by the founder even when he does not share in the private benefits. Once the professional manager has accepted to run the firm and revenues are realized, the founder has an incentive to reduce the professional manager's private benefits by monitoring more. Anticipating high levels of monitoring, the professional manager may reject the offer to run the firm. That is, the founder may over-monitor in the sense of the ex post optimal monitoring level exceeding the ex ante optimal amount (Pagano and Roell 1998). To induce the manager to accept running the firm, the founder has to commit himself not to monitor excessively. He can do so by dispersing (some of) the shares to small investors because the actual monitoring intensity is determined by the size of the founder's equity stake (Burkart, Gromb, and Panunzi 1997). In addition (or instead), the founder may offer the professional manager monetary incentives to convince him to run the firm. 
We solve the game by backward induction, beginning with the date 3 resource allocation decision. Total revenues under the professional manager are $v_{M}$. The law stipulates that $(1-\bar{\phi}) v_{M}$ must be paid out either to shareholders as dividends or to the professional manager as salary. What fraction of the remaining $\bar{\phi} v_{M}$ is actually diverted depends on monitoring. The founder monitoring with intensity $m$ can control the use of an additional fraction $m$ (or at most $\bar{\phi}$ ) of $v_{M}$. Being excluded from sharing private benefits, the founder forces the professional manager to disgorge all of them as dividends. The professional manager then has discretion over $\max \left\{0,(\bar{\phi}-m) v_{M}\right\}$ in resources. He strictly prefers to extract them as private benefits, unless he is the sole shareholder.

Since private benefit extraction is efficient, there are no gains to shareholders from using monetary incentives to resolve the conflict over resource allocation. To induce the manager to abstain from extracting an additional dollar, shareholders have to offer him this dollar as a transfer. Monetary incentives, henceforth called the wage, can, however, play a role in inducing the manager to accept the job of running the firm. Let $w v_{M}$ denote the wage paid to the professional manager when he accepts the job offer from the founder. ${ }^{4}$

At date 2, the founder chooses the monitoring intensity. For a given block $\alpha$ and for a given wage rate $w$, the founder maximizes $\alpha(1-w-\bar{\phi}+m) v_{M}-k \frac{m^{2}}{2} .{ }^{5}$ He receives a fraction $\alpha$ of the security benefits net of the wage bill less his monitoring costs. Since the law already shields $(1-\bar{\phi}) v_{M}$ of the revenues from private benefit extraction, the founder never monitors

\footnotetext{
${ }^{4}$ The subsequent analysis implicitly assumes that $\bar{\phi}+w<1$, which holds in equilibrium.

${ }^{5}$ The range $m \in[0,1]$ implies that $k \geq v_{M}$.
} 
more than $\bar{\phi}$. Hence, $m=\min \left\{\bar{\phi}, \alpha \frac{v_{M}}{k}\right\}$ and weakly increases with the block size.

At date 1, the manager accepts to run the firm if the sum of the wage and the private benefits exceeds his outside utility $c .^{6}$ The condition $(w+\bar{\phi}-m) v_{M} \geq c$ can be rewritten as

$$
m \leq \bar{m}=w+\bar{\phi}-\frac{c}{v_{M}}
$$

High levels of monitoring and strict legal rules reduce the professional manager's private benefits and may thus discourage him from running the firm. Offering him a higher wage can sway him to accept the job. Higher ownership concentration and better legal protection make it more difficult to satisfy the professional manager's participation constraint, whereas higher wages make it easier. This is the basic trade-off when ownership and management are separated.

At date 0 , the founder chooses the ownership structure and the wage to maximize his welfare $V^{s}=[1-w-\bar{\phi}+m] v_{M}-k \frac{m^{2}}{2}$ subject to the manager's participation constraint.

If the founder were to choose an ownership structure such that $\bar{\phi}<\alpha \frac{v_{M}}{k}$, the professional manager would be left with zero private benefits. Consequently, the founder would have to offer a wage $w=c$ to induce the professional manager to accept the job. Leaving some private benefits to the professional manager in exchange for a lower wage saves on monitoring costs. Hence, the founder always chooses an ownership structure such that $\bar{\phi}>\alpha \frac{v_{M}}{k}$ and $m=\alpha \frac{v_{M}}{k}$.

Inserting the monitoring level $m=\alpha \frac{v_{M}}{k}$ into the founder's welfare yields

\footnotetext{
${ }^{6}$ An alternative interpretation of the model is one where the manager has to exert an effort to generate revenues $v_{M}$ and $c$ is the disutility of the effort.
} 
$V^{S}=\left(1-w-\bar{\phi}+\frac{\alpha v_{M}}{k}\right) v_{M}-\frac{\left(\alpha v_{M}\right)^{2}}{2 k}$ with $d V^{S} / d \alpha=(1-\alpha) v_{M}{ }^{2} / k \geq 0$ and $d V^{S} / d w=-v_{M}<0$

The founder's welfare increases with ownership concentration and decreases with the wage, provided that the professional manager's participation constraint is satisfied.

A binding participation constraint is obviously in the interest of the founder as any managerial rent comes at his expense. Sometimes, however, the founder cannot avoid leaving some rents to the professional manager. More precisely, there are parameter values for which the participation constraint $(w+\bar{\phi}-m) v_{M} \geq c$ does not bind despite a fully concentrated ownership structure and a zero wage. This occurs when $\bar{\phi}>v_{M} / k+c / v_{M}$. We want to allow for the possibility of legal regimes in which the professional manager can extract a rent.

Assumption 2: $\frac{v_{M}}{k}+\frac{c}{v_{M}}<1$

Since $\bar{\phi} \leq 1$, Assumption 2 is a necessary condition for $\bar{\phi}>v_{M} / k+c / v_{M}$ to hold.

\section{Lemma 2}

$$
\begin{aligned}
& \text { i) } \quad \text { For } \quad \bar{\phi} \leq \frac{c}{v_{M}}, \quad \alpha^{*}=0, \quad w^{*}=c / v_{M}-\bar{\phi}, \quad m^{*}=0, \quad \text { and } \\
& V^{S}\left(\alpha^{*}, w^{*}, \bar{\phi}\right)=v_{M}-c \\
& \text { ii) } \quad \text { For } \frac{c}{v_{M}}<\bar{\phi} \leq \frac{c}{v_{M}}+\frac{v_{M}}{k}, \alpha^{*}=\frac{k}{v_{M}}\left(\bar{\phi}-\frac{c}{v_{M}}\right), \quad w^{*}=0, \quad m^{*}=\bar{\phi}-\frac{c}{v_{M}}, \\
& V^{S}\left(\alpha^{*}, w^{*}, \bar{\phi}\right)=v_{M}-c-\frac{k}{2}\left(\bar{\phi}-\frac{c}{v_{M}}\right)^{2} .
\end{aligned}
$$




$$
\begin{aligned}
& \text { iii) For } \quad \bar{\phi}>\frac{c}{v_{M}}+\frac{v_{M}}{k}, \quad \alpha^{*}=1, \quad w^{*}=0, \quad m^{*}=\frac{v_{M}}{k}, \quad \text { and } \\
& V^{S}\left(\alpha^{*}, w^{*}, \bar{\phi}\right)=v_{M}(1-\bar{\phi})+\frac{v_{M}^{2}}{2 k}
\end{aligned}
$$

When legal protection is strong (case i), then, even in the absence of monitoring, private benefits are insufficient to induce the professional manager to run the firm. Consequently, ownership is completely dispersed and the professional manager is offered a wage equal to the difference between his outside utility and the private benefits. The founder's resulting welfare $V^{S}\left(\alpha^{*}, w^{*}, \bar{\phi}\right)$ is at its highest possible level under separation $\left(v_{M}-c\right)$ and does not depend on the quality of legal rules.

When legal protection is moderate (case ii), expected private benefits exceed the outside utility $c$. As a result, the founder has to monitor the professional manager to limit the size of his rent. Setting the wage equal to zero minimizes the monitoring intensity that keeps the professional manager's participation constraint binding. Since monitoring is costly, this dominates all other combinations of positive wage and monitoring level that also leave no rent to the professional manager. A positive wage and concentrated ownership do not co-exist in equilibrium. Due to the monitoring costs, the founder's welfare $V^{S}\left(\alpha^{*}, w^{*}, \bar{\phi}\right)$ is below its highest possible level. Moreover, $V^{S}\left(\alpha^{*}, w^{*}, \bar{\phi}\right)$ decreases in both $\bar{\phi}$ and $k$ : less legal protection entails a higher optimal level of monitoring, and a higher $\mathrm{k}$ makes monitoring more expensive.

When legal protection is poor (case iii) the founder cannot avoid leaving a rent to the professional manager. Offering a zero wage and retaining all shares to implement a monitoring level $m=v_{M} / k$ is all that the founder can do. The resulting rent to the professional manager is 
equal to $R=\left(\bar{\phi}-\frac{v_{M}}{k}\right) v_{M}-c$. The founder's welfare $V^{S}\left(\alpha^{*}, w^{*}, \bar{\phi}\right)$ is equal to the highest possible level $\left(v_{M}-c\right)$ less monitoring costs and managerial rent. As in the range with moderate legal protection, $V^{S}\left(\alpha^{*}, w^{*}, \bar{\phi}\right)$ decreases in both $\bar{\phi}$ and $k^{7}$

We now turn to the final step of determining the conditions under which the founder chooses to hire a professional manager. The answer follows from comparing the founder's welfare under no separation $V^{N S}$ (Lemma 1) to that under separation $V^{S}$ (Lemma 2). The next Propositions describe the overall equilibrium outcomes.

\section{Proposition 1}

i) If $v_{F}+B \geq v_{M}-c$, ownership and management are never separated.

ii) If $v_{M}^{2} / 2 k \geq v_{F}+B$, ownership and management are always separated.

When the family's amenity potential $B$ exceeds the professional manager's superior ability net of his outside option ( $B \geq v_{M}-c-v_{F}$ ), separation of ownership and management is never optimal, irrespective of the quality of legal protection. A necessary condition for separation is that $B<v_{M}-c-v_{F}$. At the other extreme, if the discrepancy between the managerial abilities of the professional and the founder (or his heir) is very large, keeping management in the family is always inferior. The founder or the family retains an ownership stake of a size depending on the quality of the legal protection as described in Lemma 2, but give up control. The condition $v_{M}^{2} / 2 k \geq v_{F}+B$ is intuitive if we examine the founder's welfare under

\footnotetext{
${ }^{7}$ The conclusions of Lemma 2 also obtain if we use the efficiency of monitoring (cost parameter $k$ ) rather than the upper bound on diversion as the measure of legal shareholder protection, with one difference. Since the founder and the small shareholders have congruent interests, legal protection and monitoring are substitutes when $\bar{\phi}$ is the measure of legal protection, but complements when $k$ is the measure of legal protection.
} 
separation at its minimum when the law provides no protection $(\bar{\phi}=1)$. In this case, all dividend payments are exclusively due to monitoring, a fully concentrated ownership structure is optimal, and $V^{S}=v_{M}^{2} / 2 k$, which is still better than keeping control in the family.

Proposition 1 sheds light on some of the reasons for observing a variation in ownership structures within a country, so the legal protection of investors is held roughly constant. Even with very strong protection of investors, a founder might want to keep control in the family if the amenity potential is very large or if the heir is relatively competent. Consistent with this prediction, Demsetz and Lehn (1985) document the pervasiveness of family control in the media and professional sports companies in the United States. Conversely, even with very weak investor protection, family control is likely to be surrendered when the heir is at a particularly strong disadvantage in management. Thus, in Western Europe, one often sees professionally managed firms in relatively "technical" areas, such as utilities and telecommunications.

Consider now the parameter range of "moderate" amenity potential and relative competency of the heir: $v_{M}^{2} / 2 k<v_{F}+B<v_{M}-c$. In this range, the law shapes the attractiveness

of hiring a professional manager. Denote by $\bar{\phi}^{*} \in\left(c / v_{M}, 1\right)$ the unique value of $\bar{\phi}$ such that $V^{S}\left(\alpha^{*}, w^{*}, \bar{\phi}\right)=V^{N S}$. This value exists because $v_{M}^{2} / 2 k<v_{F}+B$.

\section{Proposition 2}

If $v_{M}^{2} / 2 k<v_{F}+B<v_{M}-c$ there are three regimes:

i) When legal shareholder protection is strong $\left(\bar{\phi} \leq c / v_{M}\right)$, ownership and management are separated, and ownership is fully dispersed.

ii) When legal protection is moderate $\left(\bar{\phi} \in\left(c / v_{M}, \bar{\phi}^{*}\right]\right)$, ownership and management are separated, and the founder retains a block. 
iii) When legal protection is poor $\left(\bar{\phi}>\bar{\phi}^{*}\right)$, there is no separation of ownership and management.

When legal rules are very protective i.e., with $\bar{\phi} \leq \frac{c}{v_{M}}$, the separation of ownership and management allows the founder to capitalize on the superior ability of the professional manager and only give up the amenity potential $B$. Strong legal protection also solves at no cost to the founder the agency conflict over the allocation of revenues. More precisely, the law restricts private benefit extraction below the professional manager's outside utility. Letting this manager divert corporate resources is part of his compensation package, which needs to be supplemented by a wage. In this case, selling all the equity and hiring a professional manager is the optimal choice for the founder.

In this model, a legal system with strong protection of outside shareholders is socially desirable. The best manager is hired to run the firm, and no resources are wasted on monitoring. This conclusion is driven by the assumption that law enforcement is free - at least from the viewpoint of the founder. If better legal protection imposes higher enforcement costs on the society, we would have to compare these costs with the social costs of private monitoring. ${ }^{8}$

Once investor protection falls below the threshold $c / v_{M}$, the separation of ownership and management involves a trade-off. On the one hand, the firm is run by a more qualified manager. On the other hand, the founder has to incur monitoring costs (and possibly leave a rent to the professional manager) as well as give up the amenity potential $B$.

When ownership and management are separated, the founder's welfare $V^{S}$ decreases with

\footnotetext{
${ }^{8}$ The private and social calculations would be further complicated when there are private costs of compliance with legal rules. For example, the costs of complying with better accounting and disclosure standards might be higher.
} 
$\bar{\phi}$, because weaker legal protection entails higher monitoring costs and (possibly) an increasing managerial rent. In contrast, when ownership and management are not separated, the founder's welfare is $v_{F}+B$ and independent of the quality of legal protection. Hence, there exists a unique threshold value $\bar{\phi}^{*}$ below which the cost of separating ownership and management (monitoring costs, managerial rent, and $B)$ is less than the gain in managerial efficiency $\left(v_{M}-c-v_{F}\right)$. In this case the founder or family simply retains an ownership stake whose size depends on legal protection (Lemma 2). Conversely, for $\phi>\bar{\phi}^{*}$ the forgone efficiency loss associated with keeping control in the family is smaller than the agency costs of separating ownership and management. This holds when the sum of $B$ and revenues under family control exceeds the net dividends under separation.

Propositions 1 and 2 can be described in a simple diagram, which shows the gains and costs of appointing a professional manager as a function of the degree of legal protection $\bar{\phi}$ (Figure 2). The gain is independent of $\bar{\phi}$ and is reflected by horizontal line $v_{M}-c-v_{F}$. The cost includes the monitoring cost, managerial rent, and the foregone amenity potential $B$. As Proposition 1 and Figure 2 show, $B$ could be very high, in which case there is no separation regardless of the legal regime, or very low, in which case there is separation for any legal regime. In the intermediate range, it follows from Lemma 2 that below $\bar{\phi} \leq c / v_{M}$ the cost is constant and equal to $B$, in the range $c / v_{M}<\bar{\phi} \leq c / v_{M}+v_{M} / k$ the cost increases at an increasing rate, and above $\bar{\phi}>c / v_{M}+v_{M} / k$ the cost increases linearly in $\bar{\phi}$. The parameter restrictions $v_{M}^{2} / 2 k<v_{F}+B<v_{M}-c$ ensures that the two lines cross at $c / v_{M}<\bar{\phi}^{*}<1$, i.e. we are in the parameter range where Proposition 2 applies. 
The model has a clear implication for how the law shapes ownership structure:

\section{Proposition 3}

When ownership and management are separated and $\alpha^{*} \in(0,1)$, more concentrated ownership structures go together with weaker legal protection, i.e., $d \alpha / d \bar{\phi} \geq 0$.

The founder's objective when ownership and management are separated is to pay the professional manager no more than his outside utility. Both legal protection and monitoring restrict the manager's extraction of private benefits. Since the law does this at no cost, the founder resorts to monitoring only to the extent that the law leaves the manager a payoff in excess of his outside utility. To keep manager's participation constraint binding, the founder has to monitor more as legal protection deteriorates. Thus, for $\bar{\phi} \in\left(c / v_{M}, c / v_{M}+v_{M} / k\right]$, legal protection and ownership concentration are inversely related when ownership and management are separated. ${ }^{9}$

Propositions 2 and 3 make strong empirical predictions, namely that family ownership should be common around the world, and relatively more common in countries with poor investor protection. Recent empirical work is consistent with these predictions. Family control is the dominant form of corporate ownership around the world. Looking at the 20 largest firms in 27 wealthy economies, La Porta et al. (1999) find that families or individuals control $30 \%$ in number and $25 \%$ in value of the top 20 firms in each country. These numbers are higher for smaller firms. Family transitions are a frequent and important occurrence: only about one third

\footnotetext{
${ }^{9}$ The (inverse) relationship between ownership concentration and legal protection depends crucially on the absence of wealth constraints of the founder and the assumed monitoring technology. In particular, the positive relationship between optimal monitoring intensity and ownership concentration relies on the assumption that the incentive to monitor depends on the ownership stake but is independent of legal protection. By contrast, when legal protection has a direct impact on the (marginal) return from monitoring the relationship between the quality of the law and ownership concentration is not monotone (Burkart and Panunzi 2001).
} 
of family controlled firms are run by their founders, the rest by descendants or by families that came to own them later. In addition, La Porta et al. (1999) show that widely held firms are more common in countries with good shareholder protection: $34 \%$ versus $16 \%$ in the countries with a low level of protection. Moreover, ownership patterns tend to be relatively stable. In short, when expropriation is a concern, firms remain family controlled.

Claessens, Djankov and Lang (2000) find that with the exception of Japan, more than $50 \%$ of all publicly traded firms in nine East Asian countries are controlled by families and that the top 15 families control significant shares of country wealth. ${ }^{10}$ East Asian countries outside Japan are indeed known for particularly poor protection of outside investors. Faccio and Lang (2002) find higher incidence of family firms in countries with inferior shareholder protection in a large sample of West European corporations. The European Corporate Governance Network (2001) documents the prevalence of concentrated corporate ownership in OECD countries.

Propositions 1 and 2 together predict both the general tendencies in ownership patterns across countries, and the existence of - possibly large - variation within each country. In our model, the sources of within-country variation are the amenity potential of control and the differences in skill between heirs and professionals. Of course, there are other potential sources of within-country variation. If firms require outside finance for expansion, or to pay inheritance taxes, ownership is likely to become dispersed. Such dispersion is compatible with the preservation of family control if shares with inferior voting rights are sold in the market. This external finance effect is likely to reinforce our finding: since valuations in countries with weaker investor protection are lower, using markets to raise funds is less attractive, raising the

\footnotetext{
${ }^{10}$ In Taiwan, the top 15 families control $20.1 \%$ of listed corporate assets; in Hong Kong, Indonesia, Korea, Malaysia, the Philippines, Singapore and Thailand, the top 15 families control more than $25 \%$ of listed corporate assets.
} 
attractiveness of family control (Shleifer and Wolfenzon 2002). Another force toward ownership dispersion - diversification - is also less powerful in markets with lower valuations.

Propositions 1 and 2 analyze the institutional conditions under which professional managers are hired. Alternatively, one can consider the managerial efficiency gain necessary to have separation of ownership and management in a regime with weak legal protection.

\section{Corollary 1}

The separation of ownership and management requires higher managerial skills in regimes with poorer legal shareholder protection.

The founder's welfare under separation $V^{S}$ increases with both the professional manager's ability (higher $v_{M}-c$ values) and the quality of the law (lower $\bar{\phi}$ values). In contrast, the founder's welfare under no separation $V^{N S}$ is independent of $\bar{\phi}$. Ceteris paribus, the switch from keeping family control to hiring a professional manager requires a more able professional manager when legal protection is less effective: Such legal regimes are associated with higher agency costs of separation of ownership and management. To make hiring a professional manager nonetheless worthwhile, the efficiency gain must be larger.

This section has analyzed how legal rules affect the trade-off between the benefits and costs of separating ownership and management. The model makes accurate predictions about the patterns of such separation in different countries. Some implications of our basic model do, however, clash with the empirical evidence. In particular, the model implies that the founder's block trades at a discount when ownership and management are separated. There is some evidence of negative block premia, but they are the exception rather than the rule. In a study of 
63 large block trades in the U.S., Barclay and Holderness (1989) report that about 20 percent were priced at a discount to the post-announcement exchange price. On average, however, block premia are both positive and higher in countries with weaker protection of outside shareholders (Zingales 1994, Nenova 2001, Dyck and Zingales 2002). The reason for the negative block premia in our model is that all shareholders benefit in proportion of their stakes from monitoring, but only the founder bears the cost. The negative block premium follows from the assumption that the founder cannot extract any private benefits, thereby ensuring that monitoring is a public good. In the next section, we allow the founder to benefit privately from his monitoring activity.

A final theoretical point concerns our assumption that ownership structure remains stable once the manager has accepted to run the company. If the founder had the opportunity and incentive to retrade ex-post, he may want to increase his stake and extract a higher fraction of private benefits from the manager. This, in turn, would affect the decision of the manager to accept the offer to run the company. For the model in this section, we can prove that, so long as trade in not anonymous, the purchase of an additional fraction of shares is not profitable for the founder. Because shareholders free ride on the entire value improvement implied by the founder's final holding, ${ }^{11}$ the founder does not make a profit on the additional shares acquired in the retrading stage. Moreover, the increase in the monitoring costs due to the larger final holding exceeds the increase in the value of the shares owned initially by the founder. Things are more complicated when trade is anonymous (DeMarzo and Urosevic 2001), or when the founder shares some of the private benefits of control with the manager, as in the next section. In these instances, we need to make the assumption that there is no retrading, or alternatively that the manager's wage can be conditioned on the founder's final equity stake.

\footnotetext{
${ }^{11}$ A proof of a similar result is contained in Burkart, Gromb, Panunzi (1997) and Pagano and Roell (1998).
} 


\section{Transferable private benefits of control}

In section III, the founder cannot by assumption extract any private benefits $\Phi$ unless he manages the firm himself. The founder's interest and that of the minority shareholders are perfectly congruent when a professional manager runs the firm. In this section we consider the other extreme, where the private benefits are perfectly transferable, thereby aligning the founder's interest in expropriation with that of the professional manager. For example, the founder and the manager can jointly create a private company that does business with the public firm, and divert cash flows to their private company through related transactions at non-market prices, such as asset sales, transfer pricing, or loan guarantees.

The possibility of sharing the spoils with the professional provides a new rationale for monitoring, namely to secure for the founder a larger share of the private benefits. Monitoring becomes a rent-seeking activity. Below we repeat the analytical steps of the previous section for this case of transferable private benefits, and establish that the existence of the three patterns of separation of ownership and management holds as before. We then explore the implications of the model for the relationship between legal protection, share value, block premium, and the agency costs of separating ownership and management. Transferable private benefits only matter in the presence of a professional manager, leaving the founder's welfare in the case of no separation unchanged (Lemma 1). We therefore move directly to the case of separation of ownership and management.

At date 3 , the law imposes that $(1-\bar{\phi}) v_{M}$ be paid out either as dividends to all shareholders or as the wage to the professional manager. The founder and the professional manager bargain over how to share the remaining $\bar{\phi} v_{M}$. For simplicity, we assume Nash bargaining with equal bargaining power. That is, both the founder and the manager receive their 
outside options, plus half the surplus. The payoff that each party obtains if bargaining were to break down, i.e., the outside option, depends on monitoring. If the founder monitors with intensity $m$, his outside option is $\alpha m v_{M}$, which corresponds to his share of security benefits salvaged from managerial expropriation. Due to the constraint $m \leq \bar{\phi}$, the outside option is equal to $\min \left\{\alpha m v_{M}, \alpha \bar{\phi} v_{M}\right\}$. The outside option of the professional manager is the fraction of revenues that he does not have to disgorge to shareholders. For the same reason, $(m \leq \bar{\phi})$, this is equal to $\max \left\{0,(\bar{\phi}-m) v_{M}\right\}$. The surplus to be shared in the bargaining between the founder and the manager is the difference between $\bar{\phi} v_{M}$ and the sum of the two outside options, and is equal to $\min \left\{(1-\alpha) m v_{M},(1-\alpha) \bar{\phi} v_{M}\right\}$. Under the assumption of equal bargaining power, the founder receives in the bargaining a payment equal his outside option plus half the surplus, or $\min \left\{\frac{1+\alpha}{2} \bar{\phi} v_{M}, m \frac{1+\alpha}{2} v_{M}\right\}$, and the manager likewise gets $\max \left\{\bar{\phi} \frac{1-\alpha}{2} v_{M},\left(\bar{\phi}-m \frac{1+\alpha}{2}\right) v_{M}\right\}$

Since these payoffs exceed their outside options, the founder and the manager always agree to set $\phi=\bar{\phi}$. They expropriate minority shareholders to the maximum, and share the spoils. ${ }^{12}$

At date 2, the founder chooses the monitoring intensity to maximize $\left[\alpha(1-w-\bar{\phi})+\frac{1+\alpha}{2} m\right] v_{M}-k \frac{m^{2}}{2}$. Since the law already protects $(1-\bar{\phi}) v_{M}$ of the revenues from extraction, there is no gain in monitoring more than $\bar{\phi}$. The founder therefore chooses $m=\min \left\{\bar{\phi}, \frac{1+\alpha}{2 k} v_{M}\right\}$. If $\bar{\phi}>(1+\alpha) v_{M} / 2 k$ holds, monitoring does not depend on the block size

\footnotetext{
${ }^{12}$ The question arises again whether there are any gains from using monetary incentives to induce the manager to abstain from extracting private benefits. At first glance this seems possible, since the manager receives only half of the surplus. While the use of such a compensation scheme is in the minority shareholders' interest, the founder prefers ex post to extract private benefits. Since such extraction is efficient, the founder is ex ante indifferent. All that matters is to keep the manager's participation constraint binding, i.e., to leave him no rents.
} 
and is purely driven by the prospect of extracting a part of the private benefits. Otherwise $\left(\bar{\phi} \leq(1+\alpha) v_{M} / 2 k\right)$, monitoring is a function of both private benefits and the ownership stake.

Indeed, decomposing the first order condition into $\alpha\left(v_{M} / k\right)+[(1-\alpha) / 2]\left(v_{M} / k\right)$ reveals the two motives for monitoring. The first term reflects monitoring in the absence of collusion aimed at preventing managerial expropriation of the founder's stake $\alpha$. The second term captures the additional monitoring that the founder undertakes to appropriate some of the private benefits. While monitoring increases as before with the block size $\alpha$, the second term implies that monitoring is positive even when the founder retains no shares, i.e., $m(0)>0$. This implies that the founder cannot withdraw from the firm. To remove this purely mechanical feature of the model, we impose the following assumption:

Assumption 3: If the founder retains less than $\underline{\alpha}>0$, he abstains from monitoring.

Assumption 3 simply means that, to monitor effectively, the founder must have some power over the manager, and for that he needs a minimum ownership stake. This stake may enable him to sit on the board, to have enough shares to convene an extraordinary shareholder meeting, to have standing in litigation, or to exercise power in other ways. When the stake of the founder is below the threshold $\underline{\alpha}$, he has no power vis-à-vis the manager. Put differently, owning a stake below $\underline{\alpha}$ and dispersing the shares among small investors enables the founder to commit not to interfere through monitoring in the running of the firm. ${ }^{13}$

When $\alpha \geq \underline{\alpha}$, the founder monitors in part to avoid expropriation by the professional manager, but he does so only to help himself. Indeed, from the minority shareholders' perspective, monitoring is a pure rent-seeking activity. The founder and the professional manager

\footnotetext{
${ }^{13}$ In the absence of collusion, fully dispersed ownership $(\alpha=0)$ ensures no monitoring $(m(0)=0)$. Introducing a threshold $\underline{\alpha}$ in Section III would have complicated the analysis without adding any insight.
} 
agree to set $\phi=\bar{\phi}$ irrespective of the monitoring intensity $m .^{14}$ This result illustrates an important difference between legal shareholder protection and monitoring: while the law protects all the shareholders, monitoring in this model is a form of self-protection by the founder, which has either positive or negative externalities for other investors.

At date 1, the manager accepts to run the firm if the wage and his share of the private benefits exceed the outside utility. The condition $(w+\bar{\phi}-m(1+\alpha) / 2) v_{M} \geq c$ can be rewritten as

$$
m \leq \bar{m} \equiv \min \left\{\bar{\phi}, \frac{(\bar{\phi}+w) v_{M}-c}{\frac{1+\alpha}{2} v_{M}}\right\}
$$

The maximum level of monitoring compatible with the professional manager's participation constraint decreases with the founder's stake. A larger block increases the founder's outside option in the bargaining, thereby reducing the share of private benefits that the professional manager obtains. Nonetheless, as $(1+\alpha) / 2 \leq 1$, the threshold $\bar{m}$ is higher for a given wage $w$ and legal protection $\bar{\phi}$ when founder and professional manager collude than in the absence of collusion. Withholding $(1-\alpha) m v_{M}$ from the minority shareholders makes it more likely that the professional manager's participation constraint is satisfied.

At date 0 , the founder chooses ownership $\alpha$ and wage $w$ to maximize his welfare

$$
V^{S}=(1-\bar{\phi}-w) v_{M}+\frac{1+\alpha}{2} m v_{M}-k \frac{m^{2}}{2}
$$

As monitoring weakly increases with the block size, the founder's welfare increases in $\alpha$ and decreases in $w$. As in the absence of collusion, the optimal ownership structure is as

\footnotetext{
${ }^{14}$ If one introduces a dead-weight loss associated with private benefit extraction, monitoring also benefits minority shareholders because the founder internalizes part of the inefficiency and hence reduces the level of diversion (Burkart and Panunzi 2001).
} 
concentrated as possible and the optimal wage as low as possible provided that the manager's participation constraint is satisfied. To simplify calculations, we impose an upper bound on $\underline{\alpha}$.

Assumption 4: $\underline{\alpha} \leq \frac{2 k c}{v_{M}^{2}}-1$

Assumption 4 is purely technical, made to restrict the number of cases. The threshold $\underline{\alpha}>0{ }^{15}$ (Assumption 3) and Assumption 4 imply that the equilibrium monitoring intensity $m^{*}$ is either zero or given by the first order condition $m=\left(1+\alpha^{*}\right) v_{M} / 2 k .{ }^{16}$ In the absence of Assumption 4, monitoring intensity for small $\bar{\phi}$ values would be determined by the legal threshold $\left(m^{*}=\bar{\phi}\right)$, leaving the ownership structure indeterminate in that range of $\bar{\phi}$ values. Nonetheless, all our results on founder welfare, share value, and separation of ownership and management are robust with respect to relaxing Assumptions 3 and 4.

\section{Lemma 3}

$$
\begin{aligned}
& \text { i) For } \bar{\phi} \leq \frac{c}{v_{M}}, \alpha<\underline{\alpha}, w^{*}=\frac{c}{v_{M}}-\bar{\phi}, m^{*}=0, \text { and } V^{S}\left(\alpha^{*}, w^{*}, \bar{\phi}\right)=v_{M}-c \\
& \text { ii) For } \frac{c}{v_{M}}<\bar{\phi} \leq \frac{c}{v_{M}}+\frac{(1+\underline{\alpha})^{2}}{8 k} v_{M}, \quad \alpha<\underline{\alpha}, \quad w^{*}=0, \quad m^{*}=0, \quad \text { and } \\
& V^{S}=(1-\bar{\phi}) v_{M} \\
& \text { iii) For } \quad \frac{c}{v_{M}}+\frac{(1+\underline{\alpha})^{2}}{8 k} v_{M}<\bar{\phi} \leq \frac{c}{v_{M}}+\frac{(1+\underline{\alpha})^{2}}{4 k} v_{M}, \quad \alpha^{*}=\underline{\alpha},
\end{aligned}
$$

\footnotetext{
${ }^{15}$ As $\underline{\alpha}>0$, Assumption 4 implies that $v_{M} / 2 k \leq c / v_{M}$.

${ }^{16}$ Rearranging Assumption 4 to $(1+\underline{\alpha}) v_{M} / 2 k \leq c / v_{M}$ shows that for all $\bar{\phi}>c / v_{M}$ the first order condition and not the constraint $m \leq \bar{\phi}$ determines the monitoring intensity. Since monitoring is zero in equilibrium for $\bar{\phi} \leq c / v_{M}$, the constraint $m \leq \bar{\phi}$ never binds in equilibrium.
} 


$$
\begin{aligned}
& w^{*}=\frac{c}{v_{M}}-\bar{\phi}+\frac{(1+\underline{\alpha})^{2}}{4 k} v_{M}, m^{*}=\frac{1+\underline{\alpha}}{2 k} v_{M}, \text { and } V^{S}=v_{M}-c-\frac{(1+\underline{\alpha})^{2}}{8 k}\left(v_{M}\right)^{2} \\
& \text { iv) } \quad \text { For } \quad \frac{c}{v_{M}}+\frac{(1+\underline{\alpha})^{2}}{4 k} v_{M}<\bar{\phi} \leq \frac{c}{v_{M}}+\frac{v_{M}}{k}, \quad \alpha^{*}=\frac{2}{v_{M}} \sqrt{k\left(\bar{\phi} v_{M}-c\right)}-1, \\
& w^{*}=0, m^{*}=\sqrt{\frac{\bar{\phi} v_{M}-c}{k}}, \text { and } V^{S}\left(\alpha^{*}, w^{*}, \bar{\phi}\right)=v_{M}-c-\frac{\bar{\phi} v_{M}-c}{2} . \\
& \text { v) } \quad \text { For } \bar{\phi}>\frac{c}{v_{M}}+\frac{v_{M}}{k}, \quad \alpha^{*}=1, \quad w^{*}=0, \quad m^{*}=\frac{v_{M}}{k}, \quad \text { and } \\
& V^{S}\left(\alpha^{*}, w^{*}, \bar{\phi}\right)=v_{M}(1-\bar{\phi})+\frac{v_{M}^{2}}{2 k}
\end{aligned}
$$

Lemma 3 - illustrated in Figure 3 - replicates Lemma 2 with an added twist due to collusion and a discontinuity in the feasible monitoring level. ${ }^{17}$ In particular, region i) coincides with region i) in Lemma 2 and region v) with region iii) of Lemma 2. The differences between transferable and non-transferable private benefits appear in the intermediate range of legal protection. $^{18}$ In region iv), weak legal protection permits private benefits to an extent that sharing them between the founder and the professional manager is compatible with the participation constraint and a zero wage. Indeed, to avoid leaving a rent to the manager, the founder has to retain $\alpha>\underline{\alpha}$ and monitor accordingly. In contrast, in regions ii) and iii), where the law is more protective, a zero wage, sharing of private benefits, and satisfying the

\footnotetext{
${ }^{17}$ There is another difference between Lemma 2 and 3. When legal protection is measured by the upper bound on diversion, the founder's welfare under separation $V^{S}$ decreases with $\bar{\phi}$ both in the case of transferable and in the case of non-transferable private benefits. When legal protection is measured by monitoring efficiency, $V^{S}$ does not always decrease with $k$ in the case of transferable private benefits (region iii) of Lemma 3). Since monitoring in this setting is also a rent-seeking activity, lower $k$ values lead to more monitoring in equilibrium - a cost ultimately paid by the founder.

${ }^{18}$ Irrespective of Assumptions 3 and 4, the equilibrium outcome with collusion is more complicated than Lemma 2. In the absence of Assumptions 3 and 4, the complication is due to the fact that monitoring may be determined by the law $\left(m^{*}=\bar{\phi}\right)$ rather than by the first order condition.
} 
professional manager's participation constraint are not compatible with each other. Because of the discontinuity in monitoring, the founder faces a trade-off between under- and overmonitoring. More precisely, the founder has the option to either not monitor or to monitor at least $m=(1+\underline{\alpha}) v_{M} / 2 k$. While abstaining from monitoring concedes a rent to the professional manager, monitoring with intensity $m=(1+\underline{\alpha}) v_{M} / 2 k$ requires a positive wage to satisfy the participation constraint. In region ii), the sum of the wage and the monitoring cost when $m=(1+\underline{\alpha}) v_{M} / 2 k$ exceeds the rent that the professional manager can extract. Hence, it is optimal to fully disperse ownership and to leave the manager with a rent of $R=\bar{\phi} v_{M}-c$. The reverse holds in region iii): over-monitoring and compensating the professional manager with a wage to satisfy the participation constraint is less costly to the founder. Consequently, the optimal ownership concentration jumps to $\alpha^{*}=\underline{\alpha}$.

Another implication of Lemma 3 is that the founder cannot gain from selling the entire company to a penniless professional manager who would raise funds in the capital market. From the discussion of the no separation case, it follows that the professional manager could raise at most $(1-\bar{\phi}) v_{M}$ in the market. Moreover, he will never pay more than $v_{M}-c$. Simple inspection shows that the founder's welfare $V^{S}$ is always at least as large as the minimum of $(1-\bar{\phi}) v_{M}$ and $v_{M}-c$. Hence selling the entire company to a penniless manager is weakly dominated by selling (some) stock in the market and hiring a professional manager.

The feature of Lemma 3 that is both crucial for the subsequent results and robust to relaxing Assumptions 3 and 4 is that the agency cost of separation of ownership and management rises as investor protections become weaker. When $\bar{\phi}$ increases, the professional manager can appropriate a larger fraction of the revenues. This in turn implies either more 
monitoring or a larger rent. Since the founder ultimately bears the agency cost, his welfare weakly decreases with $\bar{\phi}$.

The final step in analyzing the founder's decision to hire a professional manager (and to float part of the equity) is the comparison of Lemma 1 with Lemma 3. Since Lemmas 2 and 3 coincide for $\bar{\phi} \leq c / v_{M}$ and $\bar{\phi}>c / v_{M}+v_{M} / k$, Proposition 1 continues to hold. When the amenity potential is very high $\left(B>v_{M}-c-v_{F}\right)$, it is never optimal for the founder to separate ownership and management. As before, a necessary condition to have separation is $B \leq v_{M}-c-v_{F}$. Also, if the discrepancy between the competence of the professional manager and that of the founder is very large $\left(v_{M}^{2} / 2 k \geq v_{F}+B\right)$, separation is always superior.

In the remaining case $\left(v_{M}^{2} / 2 k<v_{F}+B\right)$, the decision to separate or not depends on legal protection. When legal protection is $\operatorname{good}\left(\bar{\phi} \leq c / v_{M}\right)$, ownership and management are separated, and ownership is fully dispersed. When legal protection is less strong $\left(\bar{\phi}>c / v_{M}\right)$, the founder's welfare $V^{S}$ under separation and collusion (weakly) decreases with $\bar{\phi}$. Hence, Proposition 2 also continues to hold: there exists a unique threshold $\bar{\phi}^{* *} \in\left(c / v_{M}, 1\right]$ above which the sum of agency cost and foregone amenity potential $B$ exceeds the loss in managerial efficiency, and keeping management in the family is optimal. The threshold $\bar{\phi}^{* *}$ again denotes the $\bar{\phi}$ value where $V^{S}\left(\alpha^{*}, w^{*}, \bar{\phi}\right)=V^{N S}$ holds. As we show below, it is smaller than the threshold $\bar{\phi}^{*}$ derived in the previous section. The only qualitative difference from the case with non-transferable private benefits is that separation and concentrated ownership may or may not be an equilibrium outcome. That is, the threshold value $\bar{\phi}^{* *}$ at which the founder switches to no separation may entail a concentrated or a dispersed ownership structure under separation, i.e., both $\alpha^{*}\left(\bar{\phi}^{* *}\right)>\underline{\alpha}$ 
and $\alpha^{*}\left(\bar{\phi}^{* *}\right)=0$ are possible.

From the founder's perspective, legal protection and monitoring are substitutes: both restrict the professional manager's ability to extract private benefits. While monitoring is costly, better legal protection comes at no cost to the founder. This has two implications. First, as legal protection improves, the level of monitoring falls, which in turn entails a less concentrated ownership structure. Proposition 3 thus also holds with transferable private benefits: legal protection and ownership concentration are inversely related under separation of ownership and management. Second, weaker legal protection raises the agency cost of separation. Hence, hiring a professional manager in regimes with weaker legal rules requires higher managerial skills (Corollary 1).

The quality of the law also affects share value, defined as the total amount of dividends paid out to all shareholders at the final date.

\section{Proposition 4}

Share value increases as legal shareholder protection improves.

From the minority shareholders' perspective, monitoring is not a substitute for legal protection when private benefits are transferable. Ex post, both the founder and the manager prefer to extract private benefits. As a rent-seeking activity, monitoring merely determines how the two split these private benefits. In contrast, the law prescribes that no less than $(1-\bar{\phi}) v_{M}$ is used for dividends and wage payments. Hence, the expected share value is equal to $S=(1-\phi-w) v_{M}$. For $\bar{\phi} \leq c / v_{M}$, better legal protection unambiguously increases share value 
because the reduction in private benefits exceeds the wage increase. ${ }^{19}$ Nonetheless, the minority shareholders are indifferent with respect to the quality of the legal rules because they always get what they pay for. Because the minority shareholders anticipate at date 0 that the founder and the manager will divert the fraction $\bar{\phi}$ of revenues, the founder's proceeds from selling $(1-\alpha)$ shares are equal to $(1-\alpha) S$.

Proposition 4 also holds when the founder or his family keeps control over the firm. Since the founder sets $\phi=\bar{\phi}$ at date 3 (unless $\alpha=1$ ), better laws boost share value because a larger fraction of the proceeds has to be paid out as dividends.

La Porta et al. (2002) examine the valuation of companies (relative to their assets) in different countries, with different levels of shareholder protection. They find that companies in countries with above the world median measures of shareholder protection have Tobin's Qs about $20 \%$ higher than do comparable companies in countries with below world median shareholder protection. The positive association between investor protection and the valuation of corporate assets survives a variety of controls for industry, ownership structure, and growth opportunities. Claessens et al. (2002) find similar evidence of higher valuation of companies in more protective legal regimes using data from East Asia.

The positive relationship between share value and legal protection also has implications for the value of the controlling block.

\section{Corollary 2}

Total block premium $V^{S}-S$ increases as legal shareholder protection falls.

\footnotetext{
${ }^{19}$ In contrast, variations in $k$ have no impact on share value because a more efficient monitoring technology does not benefit the minority shareholders when under collusion. This independence suggests that modeling legal (minority) shareholder protection in terms of efficient monitoring technology may not be appropriate.
} 
When $\alpha^{*} \in(\underline{\alpha}, 1)$, the founder responds to lower investor protection by monitoring more. Hence, his welfare is reduced by these extra monitoring costs (and possibly by the rent paid to the manager). In contrast, monitoring has no positive impact on share value, and the law is the only safeguard of dividends. As a result, changes in the quality of the law have a larger impact on share value than on the founder's welfare. Corollary 2 also holds when management and ownership are not separated. Since the founder does not monitor in this case, his welfare is independent of the law, while share value decreases with the quality of the law.

A number of recent empirical studies examine the valuation of block premia in different jurisdictions. For example, Zingales (1994) presents evidence of very significant premium on the high voting rights shares trading on the Milan stock exchange. Nenova (2001) explicitly compares the value of a corporate voting right across legal jurisdictions in a sample of 661 dualclass firms from 18 countries. She presents striking evidence that control is more highly valued in countries with inferior protection of minority shareholders, consistent with Corollary 2. Using a different methodology for computing block premia, Dyck and Zingales (2002) extend and confirm Nenova's findings.

In contrast to minority shareholders whose wealth is independent of the law, the founder's welfare $V^{S}$ increases with the quality of the law when ownership and management are separated. The possibility of colluding with the manager also affects the founder's welfare.

\section{Proposition 5}

Collusion between the founder and the manager increases the agency costs of separating ownership and management. 
In equilibrium, the agency cost of separating ownership from management is the sum of the monitoring cost and the managerial rent. Compared to the case with non-transferable private benefits, the equilibrium level of monitoring is higher when private benefits are transferable. This is so for two reasons. First, the rent-seeking motive induces the founder to monitor more for a given $\alpha$ and $\bar{\phi}$. Higher levels of monitoring allow the founder to appropriate a larger share of the private benefits. From an ex ante perspective, however, the founder bears the cost of such wasteful monitoring himself. Second, the professional manager receives a larger payoff for a given monitoring intensity $m$. Rather than increasing the dividends for all shareholders by $m v_{M}$, the founder and the professional manager withhold the minority shareholders' share $(1-\alpha) m v_{M}$ and split it among themselves. Consequently, collusion requires higher monitoring levels in order to avoid leaving a rent to the professional manager. When private benefits are transferable, the impossibility of fine-tuning monitoring (under-monitoring) also allows the manager to obtain a positive rent in the range $\bar{\phi} \in\left[c / v_{M}, c / v_{M}+(1+\underline{\alpha})^{2} v_{M} / 8 k\right]$. The rent in very poor legal regimes $\left(\bar{\phi}>c / v_{M}+v_{M} / k\right)$ is identical with non-transferable and transferable private benefits, as the two cases coincide once ownership is fully concentrated $(\alpha=1)$.

The present model formalizes legal shareholder protection as a limit on the share of corporate resources that the party in control can divert as private benefits. The law can protect shareholders in other ways as well. One possibility suggested by Proposition 5 is that legal rules can hinder or prevent collusion between the founder and the manager. Examples of such legal rules are equal treatment provisions and fiduciary duties. In fact, Proposition 5 provides a rationale for such rules. They reduce the agency costs of separation of ownership from 
management, thereby increasing the founder's welfare. ${ }^{20}$

Collusion influences the founder's welfare when ownership and management are separated as well as his decision whether to hire a professional manager.

\section{Corollary 3}

Collusion between the founder and the manager is detrimental to the hiring of a professional manager, i.e. $\bar{\phi}^{* *} \leq \bar{\phi}^{*}$.

When ownership and control are separated, the founder's welfare is lower with transferable than with non-transferable private benefits. In contrast, collusion has no impact on his welfare when control is kept in the family. Hiring a professional manager is therefore comparatively less attractive when private benefits are transferable.

\section{Conclusion: the separation of ownership from management}

It is often claimed that there are two paradigms of corporate governance: the AngloSaxon paradigm centered on the conflict between the shareholders and the manager, and the rest of the world paradigm where the conflict is between large and small shareholders. We show that the two paradigms are special cases of a single model of managerial succession, in which the founder must simultaneously decide whether to hire an outside professional manager (as opposed to keeping management in the family) and how much of the shares to float. We argue that this decision is to some extent shaped by the degree of legal protection of minority shareholders, and

\footnotetext{
${ }^{20}$ In contrast, minority shareholder wealth is affected neither by the quality of the law nor by collusion, except for unanticipated changes thereof. Then purchasing shares at date 0 , they pay no more than the date 3 share value.
} 
derive implications for optimal succession and ownership structures from this premise.

We show that in the regimes of the strongest legal protection of minority shareholders, the optimal solution for the founder is to hire the best professional manager and sell off the entire firm in the stock market - unless his amenity potential of keeping control in the family is huge. This gives rise to the Anglo-Saxon model, in which the law is the principal constraint on managerial discretion and the agency conflict is between the manager and small minority shareholders. With intermediate protection of minority shareholders, the founder still hires a professional manager, but the law is not strong enough to control managerial discretion, and the founder or his children must stay on as large shareholders to monitor the manager. This gives rise to the twin problems of a conflict between the manager and the controlling shareholders, but also between the two of them and minority outside investors. When the protection of minority shareholders is the weakest, the agency problems are too severe to allow for separation of ownership and management. The founding family must stay on and run the firm; they can only afford to cede control to a professional manager if they make him a member of the family. The separation of ownership and management is thus an indication of a superior corporate governance environment. The lack of such separation, and the prevalence of family firms, is evidence of financial underdevelopment.

Our analysis raises the question of why entrepreneurs do not lobby the government for better investor protection. In the model, if a country improves investor protection ex ante, before the entrepreneur has sold off any shares in the market, he would be strictly better off. On the other hand, for a founder who has already sold a substantial fraction of his company, an improvement in investor protection entails a reduction of the private benefits of control, while the gains in the valuation of publicly traded shares accrue not to him but to the public 
shareholders. Many of these founders are therefore worse off from the improvement in the corporate governance environment, and indeed the established families generally oppose such reforms in developing countries (La Porta et al. 2000b). The new entrepreneurs, as well as firms with significant needs for outside financing, would benefit from legal reform, but their voices are rarely as influential as those of publicly traded family firms in the political debate. 


\section{References}

Bebchuk, Lucien, 1999, “A Rent Extraction Theory of Corporate Ownership and Control,” NBER WP No. 7203.

Berle, Adolph, and Gardiner Means, 1932, The Modern Corporation and Private Property, (Macmillan, New York).

Bhattacharya, Utpal, and B. Ravikumar, 2001, "Capital Markets and the Evolution of Family Businesses," Journal of Business 74: 187-220.

Bhattacharya, Utpal, and B. Ravikumar, 2002, "From Cronies to Professionals: the Evolution of Family Firms,” Mimeo, University of Indiana.

Burkart, Mike, Denis Gromb, and Fausto Panunzi, 1997, "Large Shareholders, Monitoring, and the Value of the Firm," Quarterly Journal of Economics, 112: 693-728.

Burkart, Mike, and Fausto Panunzi, 2001, “Agency Conflicts, Ownership Concentration and Legal Shareholder Protection," Financial Markets Group (LSE) DP 378.

Claessens, Stijn, Djankov, Simeon, and Lang, Larry, 2000, “The Separation of Ownership and Control in East Asian Corporations," Journal of Financial Economics, 58: 81112.

Claessens, Stijn, Simeon Djankov, Joseph Fan, and Larry Lang, 2002, "Expropriation of Minority Shareholders in East Asia," Journal of Finance, forthcoming.

De Marzo, Peter and Branko Urosevic, 2000, “Optimal Trading by a Large Shareholder," Mimeo, Stanford Graduate School of Business.

Dyck, Alexander and Luigi Zingales, 2002, "Private Benefits of Control: An International Comparison,” NBER Working Paper 8711.

European Corporate Governance Network (ECGN), Fabricio Barca and Marco Becht 
(eds.), 2001, The Control of Corporate Europe, Oxford University Press.

Faccio, Mara and Larry Lang, 2002, “The Ultimate Ownership of Western European Corporations," Journal of Financial Economics, forthcoming.

Grossman, Sanford, and Oliver Hart, 1988, "One Share - One Vote, and the Market for Corporate Control," Journal of Financial Economics, 20: 175-202.

Himmelberg, Charles, Glenn Hubbard, and Inessa Love, 2001, "Investor Protection, Ownership, and Capital Allocation”', mimeo Columbia University.

Jensen, Michael and William Meckling, 1976, "Theory of the Firm: Managerial Behavior, Agency Costs and Capital Structure," Journal of Financial Economics, 3: 305-360.

Johnson, Simon, Rafael La Porta, Florencio Lopez-de-Silanes, and Andrei Shleifer, 2000, “Tunneling," American Economic Review (Papers and Proceedings), 90: 22-27.

La Porta, Rafael, Florencio Lopez-de-Silanes, and Andrei Shleifer, 1999, "Corporate Ownership around the World," Journal of Finance, 54: 471-517.

La Porta, Rafael, Florencio Lopez-de-Silanes, Andrei Shleifer, and Robert Vishny, 1997, “Legal Determinants of External Finance," Journal of Finance, 52: 1131-1150.

La Porta, Rafael, Florencio Lopez-de-Silanes, Andrei Shleifer and Robert Vishny, 1998, "Law and Finance," Journal of Political Economy, 106: 1113-55.

La Porta, Rafael, Florencio Lopez-de-Silanes, Andrei Shleifer and Robert Vishny, 2002, "Investor Protection and Corporate Valuation," Journal of Finance, forthcoming.

La Porta, Rafael, Florencio Lopez-de-Silanes, Andrei Shleifer and Robert Vishny, 2000a, “Agency Problems and Dividend Policies around the World," Journal of Finance, 55: 1-33.

La Porta, Rafael, Florencio Lopez-de-Silanes, Andrei Shleifer and Robert Vishny, 2000b, "Investor Protection and Corporate Governance," Journal of Financial Economics, 58: 3-27. 
Morck, Randall, David Stangeland, and Bernard Yeung, 2000, "Inherited Wealth, Corporate Control, and Economic Growth?” in Concentrated Corporate Ownership, Randall Morck, ed., NBER Conference Volume, University of Chicago Press.

Nenova, Tatiana, 2001, “The Value of Corporate Voting Rights and Control: a crosscountry analysis," Journal of Financial Economics, forthcoming.

Pagano, Marco and Ailsa Röell, 1998, “The Choice of Stock Ownership Structure: Agency Costs, Monitoring and the Decision to Go Public," Quarterly Journal of Economics, 113: $187-226$.

Perez-Gonzales, Francisco, 2001, “Does Inherited Control Hurt Firms’ Performance?,” Ph.D. Dissertation, Harvard University.

Shleifer, Andrei, and Robert Vishny, 1986, "Large Shareholders and Corporate Control," Journal of Political Economy, 94: 461-488.

Shleifer, Andrei, and Daniel Wolfenzon, 2002, "Investor Protection and Equity Markets," Journal of Financial Economics, forthcoming.

Siegel, Jordan, 2002, “Can Foreign Firms Bond Themselves Effectively by Submitting to U.S. Law," Mimeo, MIT.

Slovin, M. and M. Sushka, 1993, "Ownership Concentration, Corporate Control Activity, and Firm Value: Evidence from the Death of Inside Blockholders," Journal of Finance, 48: 1293-1321.

Wells, Philippe, 1998, Essays in International Entrepreneurial Finance, Ph.D. dissertation, Harvard University.

Zingales, Luigi, 1994, “The Value of a Voting Right: a Study of the Milan Stock Exchange," Review of Financial Studies, 7: 125-148. 
Figure 2: Illustration of Lemma 2, Proposition 1, and Proposition

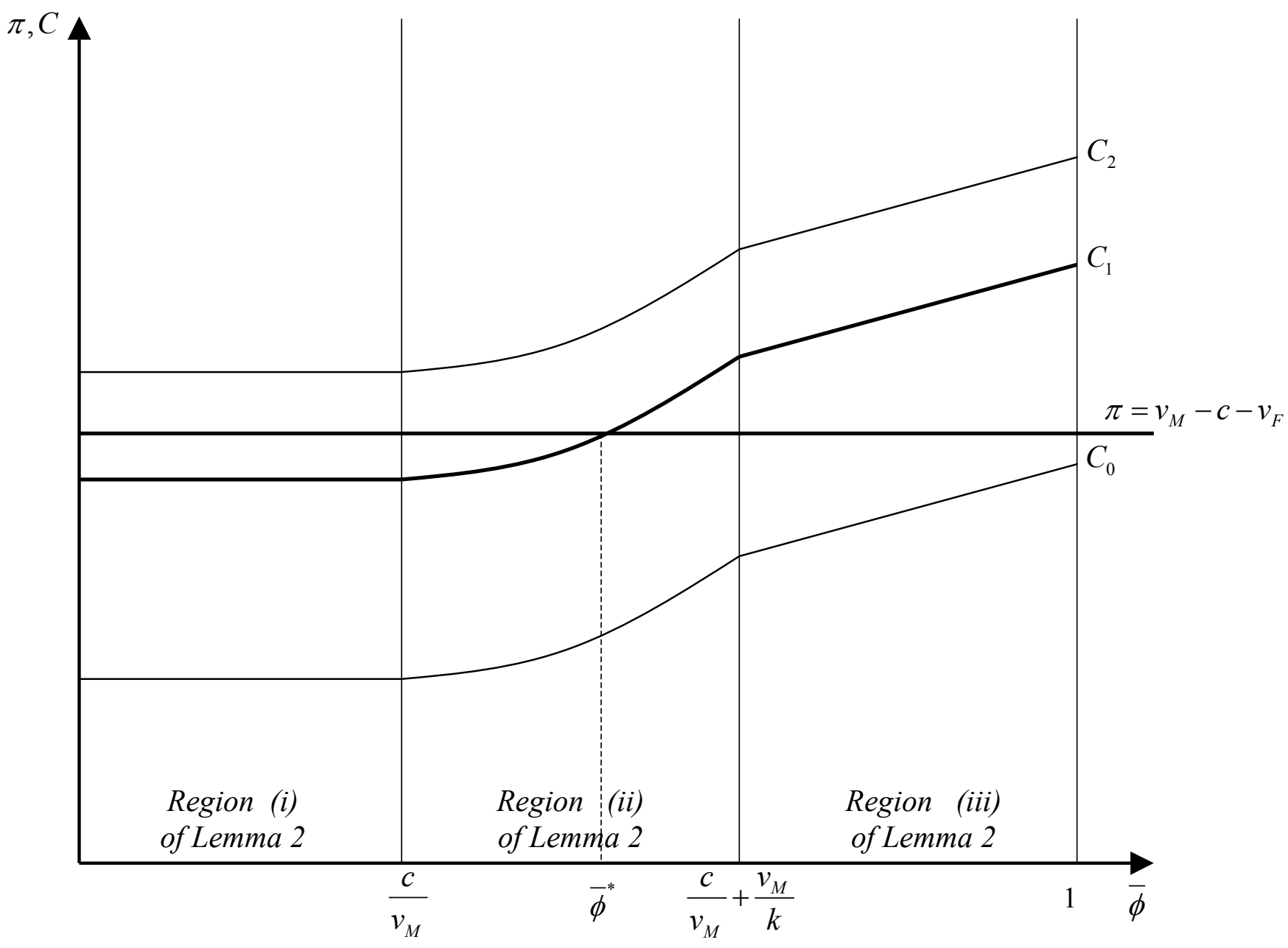

$C=$ monitoring cost + managerial rent + amenity potential $=$ cost of delegation

$\pi=v_{M}-c-v_{F}=$ benefit of delegation

$C_{1}$ obtains for $\left.\frac{v_{M}^{2}}{2 k}<v_{F}+B<v_{M}-c\right\}$ Law Matters: Proposition 2

$C_{0}$ obtains for $\frac{v_{M}^{2}}{2 k}>v_{F}+B \quad$ Law does not matter: delegation

$C_{2}$ obtains for $v_{F}+B>v_{M}-c$ Law does not matter: family management

Proposition 1 


\section{Figure 3: Illustration of Lemma}

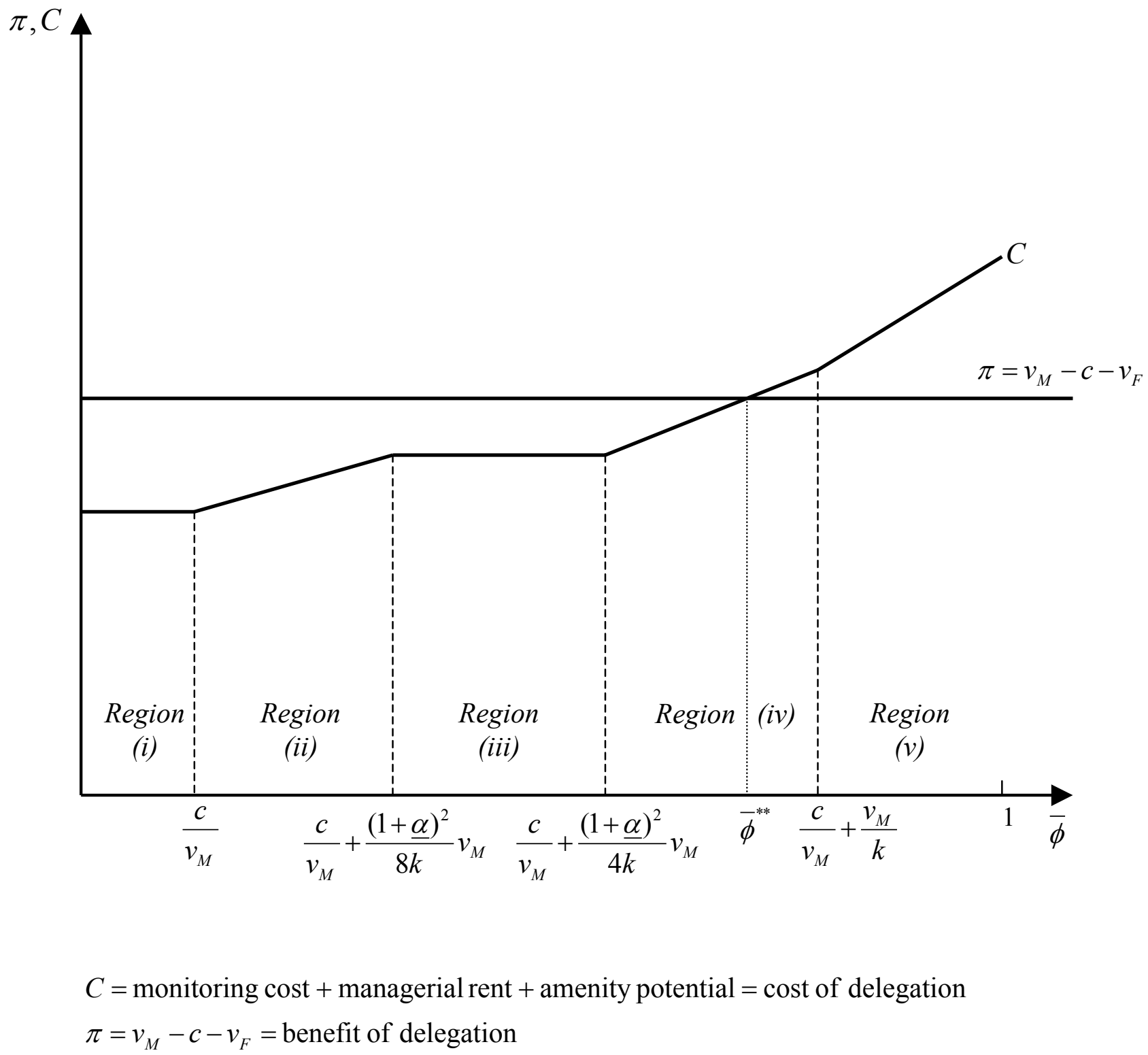




\section{Appendix}

\section{Proof of Lemma 2}

For $\bar{\phi}>\frac{c}{v_{M}}+\frac{v_{M}}{k}$ the professional manager's participation constraint $\left(w+\bar{\phi}-\alpha v_{M} / k\right) v_{M} \geq c$ is slack for any admissible pair $(\alpha, w)$. Since $d V^{S} / d \alpha>0$ and $d V^{S} / d w<0, \alpha^{*}=1$ and $w^{*}=0$ is the solution. Thus, for $\bar{\phi}>\frac{c}{v_{M}}+\frac{v_{M}}{k} m(\alpha=1)=v_{M} / k$, $V^{S}\left(\alpha^{*}, w^{*}, \bar{\phi}\right)=(1-\bar{\phi}) v_{M}+\frac{v_{M}^{2}}{2 k}$, and the professional manager receives a rent $R=\left(\bar{\phi}-\frac{v_{M}}{k}\right) v_{M}-c$ (part iii)

For $\bar{\phi} \leq \frac{c}{v_{M}}+\frac{v_{M}}{k}$ the professional manager's participation constraint binds. Rearranging this binding constraint to $\alpha=\left(w+\bar{\phi}-\frac{c}{v_{M}}\right) \frac{k}{v_{M}}$ and substituting $\alpha$ in the objective function yields $V^{S}=v_{M}-c-\frac{k}{2}\left(w+\bar{\phi}-\frac{c}{v_{M}}\right)^{2}$, which decreases with $w$. Consequently, the founder sets $w$ at the lowest value compatible with $w \geq 0$ and $\alpha \geq 0$. Hence, $w=\max \left\{0, \frac{c}{v_{M}}-\bar{\phi}\right\}$, and there are two cases: For $\bar{\phi} \leq \frac{c}{v_{M}}, \alpha^{*}=0, w^{*}=\frac{c}{v_{M}}-\bar{\phi}, m^{*}=0$, and $V^{S}\left(\alpha^{*}, w^{*}, \bar{\phi}\right)=v_{M}-c$ (part i). For $\frac{c}{v_{M}}+\frac{v_{M}}{k} \geq \bar{\phi}>\frac{c}{v_{M}}, \alpha^{*}=k\left(\frac{\bar{\phi}}{v_{M}}-\frac{c}{\left(v_{M}\right)^{2}}\right), w^{*}=0, m^{*}=\bar{\phi}-\frac{c}{v_{M}}$, and $V^{S}\left(\alpha^{*}, w^{*}, \bar{\phi}\right)=v_{M}-c-\frac{k}{2}\left(\bar{\phi}-\frac{c}{v_{M}}\right)^{2}($ part ii $)$ 


\section{Proof of Proposition 1}

By Lemma $1 V^{N S}=v_{F}+B$, and by Lemma $2 V^{S}=v_{M}-c$ for $\bar{\phi} \leq c / v_{M}$. Thus, if $B>v_{M}-c-v_{F}, V^{N S}>V^{S}$ for $\bar{\phi} \in[0,1]$. Since $V^{S}$ decreases with $\bar{\phi}, V^{S}$ reaches its minimum $v_{M}^{2} / 2 k$. at $\bar{\phi}=1$. Therefore, if $v_{F}+B<v^{2}{ }_{M} / 2 k$, then $V^{S}>V^{N S}$ for $\bar{\phi} \in[0,1]$.

\section{Proof of Proposition 2}

For $\bar{\phi} \leq c / v_{M}, V^{S}=v_{M}-c$ and $V^{N S}=v_{F}+B$. If $B<v_{M}-c-v_{F}$, then separation is always optimal. For $\frac{c}{v_{M}}+\frac{v_{M}}{k} \geq \bar{\phi}>\frac{c}{v_{M}} V^{S}\left(\alpha^{*}, w^{*}, \bar{\phi}\right)=v_{M}-c-\frac{k}{2}\left(\bar{\phi}-\frac{c}{v_{M}}\right)^{2}$ and $d V^{S} / d \bar{\phi}=-k\left(\bar{\phi}-c / v_{M}\right)<0$, while for $\bar{\phi}>\frac{c}{v_{M}}+\frac{v_{M}}{k} V^{S}\left(\alpha^{*}, w^{*}, \bar{\phi}\right)=(1-\bar{\phi}) v_{M}+\frac{v_{M}^{2}}{2 k}$ and $d V^{S} / d \bar{\phi}=-v_{M}<0$. Moreover, the two expressions for $V^{S}$ coincide when $\bar{\phi}=\frac{c}{v_{M}}+\frac{v_{M}}{k}$. Hence, $V^{S}$ decreases with $\bar{\phi}$ and is continuous in $\bar{\phi}$ for $\bar{\phi}>\frac{c}{v_{M}}$. Since $V^{N S}$ is independent of $\bar{\phi}$

(Lemma 1), there exists a unique $\bar{\phi}^{*} \in\left(c / v_{M}, 1\right)$ where $V^{N S}=V^{S}$ provided that $V^{N S}>V^{S}(\bar{\phi}=1)$ i.e., $v_{F}+B>v_{M}^{2} / 2 k$.

\section{Proof of Corollary 1}

As $V^{N S}$ is independent of $\bar{\phi}$, it suffices to show that for $\bar{\phi}>\frac{c}{v_{M}} d V^{S} / d v_{M}>0$ and $d V^{S} / d \bar{\phi}<0$. The latter is shown in the proof of Proposition 2. For $\bar{\phi}>\frac{c}{v_{M}}+\frac{v_{M}}{k}$ $d V^{S} / d v_{M}=(1-\bar{\phi})+v_{M} / k>0$. For $\frac{c}{v_{M}}+\frac{v_{M}}{k} \geq \bar{\phi}>\frac{c}{v_{M}}$ 


$$
d V^{S} / d v_{M}=1-k\left(\bar{\phi}-\frac{c}{v_{M}}\right) \frac{c}{\left(v_{M}\right)^{2}} \geq 1-k\left[\frac{c}{v_{M}}+\frac{v_{M}}{k}-\frac{c}{v_{M}}\right] \frac{c}{v_{M}^{2}}=1-\frac{c}{v_{M}}>0 \text { as } \bar{\phi} \leq \frac{c}{v_{M}}+\frac{v_{M}}{k}
$$

\section{Proof of Lemma 3}

For $\bar{\phi}>\frac{c}{v_{M}}+\frac{v_{M}}{k}$ the monitoring intensity is given by $m=\frac{1+\alpha}{2 k} v_{M} \leq \frac{v_{M}}{k}<\bar{\phi}$, and the

professional manager's participation constraint $\left(w+\bar{\phi}-\frac{1+\alpha}{2} m\right) v_{M} \geq c$ is slack for any

admissible pair $(\alpha, w)$. Hence, as in Lemma 2, $\alpha^{*}=1, w^{*}=0, m^{*}=v_{M} / k$, and

$$
V^{S}\left(\alpha^{*}, w^{*}, \bar{\phi}\right)=(1-\bar{\phi}) v_{M}+\frac{v_{M}^{2}}{2 k}(\text { part v) }
$$

Consider now the range $\bar{\phi} \leq \frac{c}{v_{M}}+\frac{v_{M}}{k}$. Suppose for the time being that the monitoring

intensity is given by the FOC $m=\frac{1+\alpha}{2 k} v_{M}$. That is, abstract from the discontinuity in monitoring

and from the possibility that $\frac{1+\alpha}{2 k} v_{M}>\bar{\phi}$. Then the participation constraint must be binding.

Rearranging the constraint to $w=\frac{c}{v_{M}}-\bar{\phi}+\frac{m(1+\alpha)}{2}$ and substituting $w$ in the founder's

objective function yields $V^{S}=v_{M}-c-k \frac{m^{2}}{2}$ which decreases with $m$. Thus, the founder

chooses the lowest monitoring intensity compatible with $m \geq 0$ and $w \geq 0$. For $\bar{\phi} \leq \frac{c}{v_{M}}, m=0$,

that is, $\alpha<\underline{\alpha}$, and $w=\frac{c}{v_{M}}-\bar{\phi}$. Otherwise, $w=0$ is optimal. The corresponding optimal

ownership concentration $\alpha=\frac{2}{v_{M}} \sqrt{k\left(\bar{\phi} v_{M}-c\right)}-1$ and monitoring intensity $m=\sqrt{\frac{\bar{\phi} v_{M}-c}{k}}$ obtain 
from using the FOC $m=\frac{1+\alpha}{2 k} v_{M}$ in the professional manager's participation constraint.

These are the solutions to the founder's maximization problem only if they satisfy the conditions that the monitoring intensity is both given by the FOC, i.e., $m^{*} \leq \bar{\phi}$, and feasible, i.e., $m^{*} \notin\left(0, \frac{1+\underline{\alpha}}{2 k} v_{M}\right)$. Zero monitoring trivially satisfies both conditions and $\alpha^{*}<\underline{\alpha}$ and $w^{*}=\frac{c}{v_{M}}-\bar{\phi}$ is indeed the solution for $\bar{\phi} \leq \frac{c}{v_{M}}$. The founder's welfare is $V^{S}\left(\alpha^{*}, w^{*}, \bar{\phi}\right)=v_{M}-c$ (part i).

For $\frac{c}{v_{M}}<\bar{\phi} \leq \frac{c}{v_{M}}+\frac{v_{M}}{k}$, the first condition $\left(m^{*} \leq \bar{\phi}\right)$ is equivalent to $\sqrt{\frac{\bar{\phi} v_{M}-c}{k}} \leq \bar{\phi}$ which is always satisfied because, by Assumption $4, \frac{v_{M}}{2 k} \leq \frac{c}{v_{M}}$. Given $m=\sqrt{\frac{\bar{\phi} v_{M}-c}{k}}$, the second condition $\left(m^{*} \geq \frac{1+\underline{\alpha}}{2 k} v_{M}\right)$ is equivalent to $\bar{\phi} \geq \frac{c}{v_{M}}+\frac{(1+\underline{\alpha})^{2}}{4 k} v_{M}$. Therefore, $w^{*}=0$, $\alpha^{*}=\frac{2}{v_{M}} \sqrt{k\left(\bar{\phi} v_{M}-c\right)}-1$, and $m^{*}=\sqrt{\frac{\bar{\phi} v_{M}-c}{k}}$ is the solution only for $\frac{c}{v_{M}}+\frac{(1+\underline{\alpha})^{2}}{4 k} v_{M}<\bar{\phi} \leq \frac{c}{v_{M}}+\frac{v_{M}}{k}$. The founder's resulting welfare is $V^{S}\left(\alpha^{*}, w^{*}, \bar{\phi}\right)=v_{M}-c-\frac{\bar{\phi} v_{M}-c}{2}($ part iv) For $\frac{c}{v_{M}}<\bar{\phi} \leq \frac{c}{v_{M}}+\frac{(1+\underline{\alpha})^{2}}{4 k} v_{M}$, the only two possible optimal levels of monitoring are $m=0$ and $m=\frac{1+\underline{\alpha}}{2 k} v_{M}$. (Note that $1+\underline{\alpha} \leq \frac{2 k c}{v_{M}^{2}}$ (Assumption 4) implies that 
$\frac{1+\underline{\alpha}}{2 k} v_{M} \leq \frac{2 k c}{2 k v_{M}^{2}} v_{M}=\frac{c}{v_{M}}<\bar{\phi}$.) If $m=0$ (that is, $\alpha<\underline{\alpha}$ ), $w=0$ and $V^{S}=(1-\bar{\phi}) v_{M}$. If $m=\frac{1+\underline{\alpha}}{2 k} v_{M}$ (i.e., $\alpha=\underline{\alpha}$ ), the participation constraint implies $w=\frac{c}{v_{M}}-\bar{\phi}+\frac{(1+\underline{\alpha})^{2}}{4 k} v_{M}$, and $V^{S}=v_{M}-c-\frac{(1+\underline{\alpha})^{2}}{8 k} v_{M}^{2}$. Simple calculations show that $v_{M}-c-\frac{(1+\underline{\alpha})^{2}}{8 k} v_{M}^{2}>(1-\bar{\phi}) v_{M}$ holds for $\bar{\phi}>\frac{c}{v_{M}}+\frac{(1+\underline{\alpha})^{2}}{8 k} v_{M}$. Thus, for $\frac{c}{v_{M}}<\bar{\phi} \leq \frac{c}{v_{M}}+\frac{(1+\underline{\alpha})^{2}}{8 k} v_{M}, \alpha^{*}<\underline{\alpha}, w^{*}=0, m^{*}=0$, and $V^{S}\left(\alpha^{*}, w^{*}, \bar{\phi}\right)=(1-\bar{\phi}) v_{M}$ (part ii), while for $\frac{c}{v_{M}}+\frac{(1+\underline{\alpha})^{2}}{8 k} v_{M}<\bar{\phi} \leq \frac{c}{v_{M}}+\frac{(1+\underline{\alpha})^{2}}{4 k} v_{M}, \quad \alpha^{*}=\underline{\alpha}$, $w^{*}=\frac{c}{v_{M}}-\bar{\phi}+\frac{(1+\underline{\alpha})^{2}}{4 k} v_{M}, m^{*}=\frac{1+\underline{\alpha}}{2 k} v_{M}$, and $V^{S}\left(\alpha^{*}, w^{*}, \bar{\phi}\right)=v_{M}-c-\frac{(1+\underline{\alpha})^{2}}{8 k} v_{M}^{2}$ (part iii).

\section{Proof of Proposition 4}

Over the five regions of Lemma 3 share value $S=\left(1-\bar{\phi}-w^{*}\right) v_{M}$ (weakly) decreases with $\bar{\phi}$ as the subsequent derivations of the explicit expression of $S$ in each region show.

For $\bar{\phi} \leq \frac{c}{v_{M}} S=\left(1-\bar{\phi}-w^{*}\right) v_{M}=v_{M}-c$ holds.

For $\frac{c}{v_{M}}<\bar{\phi} \leq \frac{c}{v_{M}}+\frac{(1+\underline{\alpha})^{2}}{8 k} v_{M} S=(1-\bar{\phi}) v_{M}$ which decreases with $\bar{\phi}$ and is equal

$S=v_{M}-c$ at the lower bound of the interval, i.e., for $\bar{\phi}=\frac{c}{v_{M}}$, and equal to

$S=v_{M}-c-\frac{(1+\underline{\alpha})^{2}}{8 k} v_{M}^{2}$ at the upper bound, i.e., for $\bar{\phi}=\frac{c}{v_{M}}+\frac{(1+\underline{\alpha})^{2}}{8 k} v_{M}$.

For $\frac{c}{v_{M}}+\frac{(1+\underline{\alpha})^{2}}{8 k} v_{M}<\bar{\phi} \leq \frac{c}{v_{M}}+\frac{(1+\underline{\alpha})^{2}}{4 k} v_{M} \quad S=v_{M}-c-\frac{(1+\underline{\alpha})^{2}}{4 k} v_{M}^{2}$ holds. 
For $\frac{c}{v_{M}}+\frac{(1+\underline{\alpha})^{2}}{4 k} v_{M}<\bar{\phi} \leq \frac{c}{v_{M}}+\frac{v_{M}}{k} S=(1-\bar{\phi}) v_{M}$ which decreases with $\bar{\phi}$ and is equal to $S=v_{M}-c-\frac{(1+\underline{\alpha})^{2}}{4 k} v_{M}^{2}$ at the lower bound of the interval, i.e., for $\bar{\phi}=\frac{c}{v_{M}}+\frac{(1+\underline{\alpha})^{2}}{4 k} v_{M}$ and equal to $S=v_{M}-c-\frac{v_{M}^{2}}{k}$ at the upper bound, i.e., for $\bar{\phi}=\frac{c}{v_{M}}+\frac{v_{M}}{k}$.

For $\bar{\phi}>\frac{c}{v_{M}}+\frac{v_{M}}{k}, S=(1-\bar{\phi}) v_{M}$ which decreases with $\bar{\phi}$ and is equal to $S=v_{M}-c-\frac{v_{M}^{2}}{k}$ at the lower bound of the interval, i.e., for $\bar{\phi}=\frac{c}{v_{M}}+\frac{v_{M}}{k}$.

\section{Proof of Corollary 2}

The block premium is meaningful only in the range where $1>\alpha^{*}>0$, i.e. in regions iii)

and iv) of Lemma 3. For $\frac{c}{v_{M}}+\frac{(1+\underline{\alpha})^{2}}{8 k} v_{M}<\bar{\phi} \leq \frac{c}{v_{M}}+\frac{(1+\underline{\alpha})^{2}}{4 k} v_{M} \quad \alpha^{*}=\underline{\alpha}$ and $V^{S}\left(\alpha^{*}, w^{*}, \bar{\phi}\right)-S=\frac{(1+\underline{\alpha})^{2}}{8 k} v_{M}^{2}$. For $\frac{c}{v_{M}}+\frac{(1+\underline{\alpha})^{2}}{4 k} v_{M}<\bar{\phi} \leq \frac{c}{v_{M}}+\frac{v_{M}}{k} \quad \alpha^{*}=\frac{2}{v_{M}} \sqrt{k\left(\bar{\phi} v_{M}-c\right)}-1$ and $V^{S}\left(\alpha^{*}, w^{*}, \bar{\phi}\right)-S=\frac{\bar{\phi} v_{M}-c}{2}$ which increases with $\bar{\phi}$ and is equal to $V^{S}\left(\alpha^{*}, w^{*}, \bar{\phi}\right)-S=\frac{(1+\underline{\alpha})^{2}}{8 k} v_{M}^{2}$ at the lower bound of the interval, i.e., for $\bar{\phi}=\frac{c}{v_{M}}+\frac{(1+\underline{\alpha})^{2}}{4 k} v_{M}$.

\section{Proof of Proposition 5}

Denote by $V^{S_{N C}}$ the founder's welfare in the absence of collusion (Lemma 2) and by 
$V^{S_{C}}$ his welfare with collusion (Lemma 3). For $\frac{c}{v_{M}}<\bar{\phi} \leq \frac{c}{v_{M}}+\frac{v_{M}}{k} V^{S_{N C}} \geq V^{S_{C}}$ as the subsequent comparisons show, while $V^{S_{N C}}$ and $V^{S_{C}}$ coincide for $\bar{\phi} \leq \frac{c}{v_{M}}$ and for $\bar{\phi}>\frac{c}{v_{M}}+\frac{v_{M}}{k}$, i.e., in regions i) and v) of Lemma 3.

$$
\text { For } \frac{c}{v_{M}}<\bar{\phi} \leq \frac{c}{v_{M}}+\frac{(1+\underline{\alpha})^{2} v_{M}}{8 k}, V^{S_{N C}} \geq V^{S_{C}} \text { is equivalent to } c+\frac{k}{2}\left(\bar{\phi}-\frac{c}{v_{M}}\right)^{2} \leq \bar{\phi} v_{M} \text {. }
$$

Rearranging this inequality we obtain $\frac{k}{2 v_{M}}\left(\bar{\phi}-\frac{c}{v_{M}}\right)^{2} \leq\left(\bar{\phi}-\frac{c}{v_{M}}\right)$ which can be rewritten as $\bar{\phi} \leq \frac{c}{v_{M}}+2 \frac{v_{M}}{k}$. This condition is always satisfied for $\bar{\phi} \leq \frac{c}{v_{M}}+\frac{(1+\underline{\alpha})^{2} v_{M}}{8 k}$ For $\frac{c}{v_{M}}+\frac{(1+\underline{\alpha})^{2} v_{M}}{8 k}<\bar{\phi} \leq \frac{c}{v_{M}}+\frac{(1+\underline{\alpha})^{2} v_{M}}{4 k}, V^{S_{N C}} \geq V^{S_{C}}$ is equivalent to $\frac{k}{2}\left(\bar{\phi}-\frac{c}{v_{M}}\right)^{2} \leq \frac{(1+\underline{\alpha})^{2}}{8 k} v_{M}^{2}$. Since the LHS increases with $\bar{\phi}$ it is sufficient to check the inequality is satisfied at the upper bound of the interval. Substituting $\bar{\phi}=\frac{c}{v_{M}}+\frac{(1+\underline{\alpha})^{2} v_{M}}{4 k}$ into the inequality and rearranging yields $\frac{(1+\underline{\alpha})}{2} \leq 1$ which always holds. For $\frac{c}{v_{M}}+\frac{(1+\underline{\alpha})^{2} v_{M}}{4 k}<\bar{\phi} \leq \frac{c}{v_{M}}+\frac{v_{M}}{k}, V^{S_{N C}} \geq V^{S_{C}}$ is equivalent to $\frac{k}{2}\left(\bar{\phi}-\frac{c}{v_{M}}\right)^{2} \leq \frac{\bar{\phi} v_{M}-c}{2}$. Rearranging this inequality we obtain $k\left(\bar{\phi}-\frac{c}{v_{M}}\right)^{2} \leq v_{M}\left(\bar{\phi}-\frac{c}{v_{M}}\right)$ which can be rewritten as $\bar{\phi}-\frac{c}{v_{M}} \leq \frac{v_{M}}{k}$. This condition is always satisfied for $\bar{\phi} \leq \frac{c}{v_{M}}+\frac{v_{M}}{k}$. 


\title{
NOTE DI LAVORO DELLA FONDAZIONE ENI ENRICO MATTEI Fondazione Eni Enrico Mattei Working Papers Series \\ Our working papers are available on the Internet at the following addresses: Server $W W W$ : WWW.FEEM.IT \\ Anonymous FTP: FTP.FEEM.IT \\ http://papers.ssrn.com/abstract_id=XXXXXX
}

\begin{abstract}
SUST $\quad 1.2001 \quad$ Inge MAYERES and Stef PROOST: Should Diesel Cars in Europe be Discouraged?
SUST 2.2001 Paola DORIA and Davide PETTENELLA: The Decision Making Process in Defining and Protecting Critical Natural Capital

CLIM $3.2001 \quad$ Alberto PENCH: Green Tax Reforms in a Computable General Equilibrium Model for Italy

CLIM 4.2001 Maurizio BUSSOLO and Dino PINELLI: Green Taxes: Environment, Employment and Growth

CLIM 5.2001 Marco STAMPINI: Tax Reforms and Environmental Policies for Italy

ETA $\quad 6.2001$

CLIM $\quad 7.2001$

Walid OUESLATI: Environmental Fiscal Policy in an Endogenous Growth Model with Human Capital

Umberto CIORBA, Alessandro LANZA and Francesco PAULI: Kyoto Commitment and Emission Trading: a European Union Perspective

MGMT 8.2001 Brian SLACK (xlv): Globalisation in Maritime Transportation: Competition, uncertainty and implications for port development strategy

VOL 9.2001 Giulia PESARO: Environmental Voluntary Agreements: A New Model of Co-operation Between Public and Economic Actors

VOL $\quad 10.2001 \quad$ Cathrine HAGEM: Climate Policy, Asymmetric Information and Firm Survival

ETA 11.2001 Sergio CURRARINI and Marco MARINI: A Sequential Approach to the Characteristic Function and the Core in Games with Externalities

ETA 12.2001 Gaetano BLOISE, Sergio CURRARINI and Nicholas KIKIDIS: Inflation and Welfare in an OLG Economy with a Privately Provided Public Good

KNOW 13.2001 Paolo SURICO: Globalisation and Trade: A "New Economic Geography" Perspective

ETA $\quad 14.2001$ Valentina BOSETTI and Vincenzina MESSINA: Quasi Option Value and Irreversible Choices

CLIM $\quad 15.2001$

Guy ENGELEN (xlii): Desertification and Land Degradation in Mediterranean Areas: from Science to Integrated Policy Making

SUST $\quad 16.2001$ Julie Catherine SORS: Measuring Progress Towards Sustainable Development in Venice: A Comparative Assessment of Methods and Approaches

Julie Catherine SORS: Public Participation in Local Agenda 21: A Review of Traditional and Innovative Tools

CLIM $\quad 18.2001$

Johan ALBRECHT and Niko GOBBIN: Schumpeter and the Rise of Modern Environmentalism

VOL 19.2001 Rinaldo BRAU, Carlo CARRARO and Giulio GOLFETTO (xliii): Participation Incentives and the Design of Voluntary Agreements

ETA $20.2001 \quad$ Paola ROTA: Dynamic Labour Demand with Lumpy and Kinked Adjustment Costs

ETA $21.2001 \quad$ Paola ROTA: Empirical Representation of Firms' Employment Decisions by an (S,s) Rule

ETA 22.2001 Paola ROTA: What Do We Gain by Being Discrete? An Introduction to the Econometrics of Discrete Decision Processes

PRIV 23.2001 Stefano BOSI, Guillaume GIRMANS and Michel GUILLARD: Optimal Privatisation Design and Financial Markets

KNOW 24.2001 Giorgio BRUNELLO, Claudio LUPI, Patrizia ORDINE, and Maria Luisa PARISI: Beyond National Institutions: Labour Taxes and Regional Unemployment in Italy

ETA 25.2001 Klaus CONRAD: Locational Competition under Environmental Regulation when Input Prices and Productivity $\underline{\text { Differ }}$

PRIV $26.2001 \quad \overline{\text { Bernardo BORTOLOTTI, Juliet D'SOUZA, Marcella FANTINI and William L. MEGGINSON: Sources of }}$ Performance Improvement in Privatised Firms: A Clinical Study of the Global Telecommunications Industry

CLIM 27.2001 Frédéric BROCHIER and Emiliano RAMIERI: Climate Change Impacts on the Mediterranean Coastal Zones

ETA 28.2001 Nunzio CAPPUCCIO and Michele MORETTO: Comments on the Investment-Uncertainty Relationship in a Real Option Model

KNOW 29.2001 Giorgio BRUNELLO: Absolute Risk Aversion and the Returns to Education

CLIM 30.2001 ZhongXiang ZHANG: Meeting the Kyoto Targets: The Importance of Developing Country Participation

ETA 31.2001 Jonathan D. KAPLAN, Richard E. HOWITT and Y. Hossein FARZIN: An Information-Theoretical Analysis of Budget-Constrained Nonpoint Source Pollution Control

MGMT $32.2001 \quad$ Roberta SALOMONE and Giulia GALLUCCIO: Environmental Issues and Financial Reporting Trends

Coalition

Theory

ETA $\quad 34.200$

33.2001 Shlomo WEBER and Hans WIESMETH: From Autarky to Free Trade: The Impact on Environment

34.2001 Margarita GENIUS and Elisabetta STRAZZERA: Model Selection and Tests for Non Nested Contingent Valuation Models: An Assessment of Methods
\end{abstract}


NRM 35.2001 Carlo GIUPPONI: The Substitution of Hazardous Molecules in Production Processes: The Atrazine Case Study in Italian Agriculture

KNOW 36.2001 Raffaele PACI and Francesco PIGLIARU: Technological Diffusion, Spatial Spillovers and Regional Convergence in Europe

PRIV 37.2001 Bernardo BORTOLOTTI: Privatisation, Large Shareholders, and Sequential Auctions of Shares

CLIM 38.2001 Barbara BUCHNER: What Really Happened in The Hague? Report on the COP6, Part I, 13-25 November 2000, The Hague, The Netherlands

PRIV 39.2001 Giacomo CALZOLARI and Carlo SCARPA: Regulation at Home, Competition Abroad: A Theoretical Framework

KNOW $40.2001 \quad$ Giorgio BRUNELLO: On the Complementarity between Education and Training in Europe

Coalition 41.2001 Alain DESDOIGTS and Fabien MOIZEAU (xlvi): Multiple Politico-Economic Regimes, Inequality and Growth

Theory

Network

Coalition

42.2001

Parkash CHANDER and Henry TULKENS (xlvi): Limits to Climate Change

Coalition

Theory

Network

Coalition

Theory

Network

NRM

43.2001

Michael FINUS and Bianca RUNDSHAGEN (xlvi): Endogenous Coalition Formation in Global Pollution $\underline{\text { Control }}$

44.2001 Wietze LISE, Richard S.J. TOL and Bob van der ZWAAN (xlvi): Negotiating Climate Change as a Social $\underline{\text { Situation }}$

45.2001 Mohamad R. KHAWLIE (xlvii): The Impacts of Climate Change on Water Resources of Lebanon- Eastern Mediterranean

NRM 46.2001 Mutasem EL-FADEL and E. BOU-ZEID (xlvii): Climate Change and Water Resources in the Middle East: Vulnerability, Socio-Economic Impacts and Adaptation

NRM 47.2001 Eva IGLESIAS, Alberto GARRIDO and Almudena GOMEZ (xlvii): An Economic Drought Management Index to Evaluate Water Institutions' Performance Under Uncertainty and Climate Change

CLIM $\quad 48.2001 \quad$ Wietze LISE and Richard S.J. TOL (xlvii): Impact of Climate on Tourist Demand

CLIM 49.2001 Francesco BOSELLO, Barbara BUCHNER, Carlo CARRARO and Davide RAGGI: Can Equity Enhance Efficiency? Lessons from the Kyoto Protocol

SUST $\quad 50.2001 \quad$ Roberto ROSON (xlviii): Carbon Leakage in a Small Open Economy with Capital Mobility

SUST 51.2001 Edwin WOERDMAN (xlviii): Developing a European Carbon Trading Market: Will Permit Allocation Distort Competition and Lead to State Aid?

SUST $52.2001 \quad$ Richard N. COOPER (xlviii): The Kyoto Protocol: A Flawed Concept

SUST

SUST

53.2001 Kari KANGAS (xlviii): Trade Liberalisation, Changing Forest Management and Roundwood Trade in Europe

54.2001 Xueqin ZHU and Ekko VAN IERLAND (xlviii): Effects of the Enlargement of EU on Trade and the Environment

SUST 55.2001 M. Ozgur KAYALICA and Sajal LAHIRI (xlviii): Strategic Environmental Policies in the Presence of Foreign Direct Investment

SUST 56.2001 Savas ALPAY (xlviii): Can Environmental Regulations be Compatible with Higher International Competitiveness? Some New Theoretical Insights

SUST 57.2001 Roldan MURADIAN, Martin O'CONNOR, Joan MARTINEZ-ALER (xlviii): Embodied Pollution in Trade: Estimating the "Environmental Load Displacement" of Industrialised Countries

SUST 58.2001 Matthew R. AUER and Rafael REUVENY (xlviii): Foreign Aid and Direct Investment: Key Players in the Environmental Restoration of Central and Eastern Europe

SUST 59.2001 Onno J. KUIK and Frans H. OOSTERHUIS (xlviii): Lessons from the Southern Enlargement of the EU for the Environmental Dimensions of Eastern Enlargement, in particular for Poland

ETA 60.2001 Carlo CARRARO, Alessandra POME and Domenico SINISCALCO (xlix): Science vs. Profit in Research: Lessons from the Human Genome Project

CLIM 61.2001 Efrem CASTELNUOVO, Michele MORETTO and Sergio VERGALLI: Global Warming, Uncertainty and Endogenous Technical Change: Implications for Kyoto

PRIV 62.2001 Gian Luigi ALBANO, Fabrizio GERMANO and Stefano LOVO: On Some Collusive and Signaling Equilibria in Ascending Auctions for Multiple Objects

CLIM 63.2001 Elbert DIJKGRAAF and Herman R.J. VOLLEBERGH: $\underline{\text { A Note on Testing for Environmental Kuznets Curves }}$ with Panel Data

CLIM 64.2001 Paolo BUONANNO, Carlo CARRARO and Marzio GALEOTTI: Endogenous Induced Technical Change and the Costs of Kyoto

CLIM 65.2001 Guido CAZZAVILLAN and Ignazio MUSU (1): Transitional Dynamics and Uniqueness of the Balanced-Growth Path in a Simple Model of Endogenous Growth with an Environmental Asset

CLIM 66.2001 Giovanni BAIOCCHI and Salvatore DI FALCO (1): Investigating the Shape of the EKC: A Nonparametric Approach

CLIM 67.2001 Marzio GALEOTTI, Alessandro LANZA and Francesco PAULI (1): Desperately Seeking (Environmental) Kuznets: A New Look at the Evidence

CLIM 68.2001 Alexey VIKHLYAEV (xlviii): The Use of Trade Measures for Environmental Purposes - Globally and in the EU Context

NRM 69.2001 Gary D. LIBECAP and Zeynep K. HANSEN (li): $\underline{\text { U.S. Land Policy, Property Rights, and the Dust Bowl of the }}$ $\underline{1930 \mathrm{~s}}$ 
Lee J. ALSTON, Gary D. LIBECAP and Bernardo MUELLER (li): Land Reform Policies, The Sources of Violent Conflict and Implications for Deforestation in the Brazilian Amazon

CLIM $71.2001 \quad$ Claudia KEMFERT: Economy-Energy-Climate Interaction - The Model WIAGEM -

SUST 72.2001 Paulo A.L.D. NUNES and Yohanes E. RIYANTO: Policy Instruments for Creating Markets for Bodiversity: Certification and Ecolabeling

SUST $\quad 73.2001 \quad$ Paulo A.L.D. NUNES and Erik SCHOKKAERT (lii): Warm Glow and Embedding in Contingent Valuation

SUST 74.2001 Paulo A.L.D. NUNES, Jeroen C.J.M. van den BERGH and Peter NIJKAMP (lii): Ecological-Economic Analysis and Valuation of Biodiversity

VOL 75.2001 Johan EYCKMANS and Henry TULKENS (li): Simulating Coalitionally Stable Burden Sharing Agreements for the Climate Change Problem

PRIV 76.2001 Axel GAUTIER and Florian HEIDER: What Do Internal Capital Markets Do? Redistribution vs. Incentives

PRIV 77.2001 Bernardo BORTOLOTTI, Marcella FANTINI and Domenico SINISCALCO: Privatisation around the World: New Evidence from Panel Data

ETA $78.2001 \quad$ Toke S. AIDT and Jayasri DUTTA (li): Transitional Politics. Emerging Incentive-based Instruments in Environmental Regulation

ETA 79.2001 Alberto PETRUCCI: Consumption Taxation and Endogenous Growth in a Model with New Generations

ETA 80.2001 Pierre LASSERRE and Antoine SOUBEYRAN (li): A Ricardian Model of the Tragedy of the Commons

ETA 81.2001 Pierre COURTOIS, Jean Christophe PÉREAU and Tarik TAZDAÏT: An Evolutionary Approach to the Climate Change Negotiation Game

NRM 82.2001 Christophe BONTEMPS, Stéphane COUTURE and Pascal FAVARD: Is the Irrigation Water Demand Really Convex?

NRM 83.2001 Unai PASCUAL and Edward BARBIER: A Model of Optimal Labour and Soil Use with Shifting Cultivation

CLIM 84.2001 Jesper JENSEN and Martin Hvidt THELLE: What are the Gains from a Multi-Gas Strategy?

CLIM 85.2001 Maurizio MICHELINI (liii): IPCC "Summary for Policymakers" in TAR. Do its results give a scientific support always adequate to the urgencies of Kyoto negotiations?

CLIM

CLIM

86.2001 Claudia KEMFERT (liii): Economic Impact Assessment of Alternative Climate Policy Strategies

ETA $\quad 88.2001$ Cesare DOSI and Michele MORETTO: Global Warming and Financial Umbrellas

ETA $\quad 89.200$ Elena BONTEMPI, Alessandra DEL BOCA, Alessandra FRANZOSI, Marzio GALEOTTI and Paola ROTA: Capital Heterogeneity: Does it Matter? Fundamental $Q$ and Investment on a Panel of Italian Firms Efrem CASTELNUOVO and Paolo SURICO: $\underline{\text { Model Uncertainty, Optimal Monetary Policy and the Preferences }}$ of the Fed

CLIM 90.2001 Umberto CIORBA, Alessandro LANZA and Francesco PAULI: Kyoto Protocol and Emission Trading: Does the US Make a Difference?

CLIM 91.2001 ZhongXiang ZHANG and Lucas ASSUNCAO: Domestic Climate Policies and the WTO

SUST 92.2001 Anna ALBERINI, Alan KRUPNICK, Maureen CROPPER, Nathalie SIMON and Joseph COOK (lii): The Willingness to Pay for Mortality Risk Reductions: A Comparison of the United States and Canada

SUST 93.2001 Riccardo SCARPA, Guy D. GARROD and Kenneth G. WILLIS (lii): Valuing Local Public Goods with Advanced Stated Preference Models: Traffic Calming Schemes in Northern England

CLIM 94.2001 Ming CHEN and Larry KARP: Environmental Indices for the Chinese Grain Sector

CLIM 95.2001 Larry KARP and Jiangfeng ZHANG: Controlling a Stock Pollutant with Endogenous Investment and Asymmetric Information

ETA $96.2001 \quad$ Michele MORETTO and Gianpaolo ROSSINI: On the Opportunity Cost of Nontradable Stock Options

SUST 97.2001 Elisabetta STRAZZERA, Margarita GENIUS, Riccardo SCARPA and George HUTCHINSON: The Effect of Protest Votes on the Estimates of Willingness to Pay for Use Values of Recreational Sites

NRM 98.2001 Frédéric BROCHIER, Carlo GIUPPONI and Alberto LONGO: Integrated Coastal Zone Management in the Venice Area - Perspectives of Development for the Rural Island of Sant'Erasmo

NRM 99.2001 Frédéric BROCHIER, Carlo GIUPPONI and Julie SORS: Integrated Coastal Management in the Venice AreaPotentials of the Integrated Participatory Management Approach

NRM 100.2001 Frédéric BROCHIER and Carlo GIUPPONI: Integrated Coastal Zone Management in the Venice Area - A Methodological Framework

PRIV 101.2001 Enrico C. PEROTTI and Luc LAEVEN: Confidence Building in Emerging Stock Markets

CLIM 102.2001 Barbara BUCHNER, Carlo CARRARO and Igor CERSOSIMO: On the Consequences of the U.S. Withdrawal from the Kyoto/Bonn Protocol

SUST 103.2001 Riccardo SCARPA, Adam DRUCKER, Simon ANDERSON, Nancy FERRAES-EHUAN, Veronica GOMEZ, Carlos R. RISOPATRON and Olga RUBIO-LEONEL: Valuing Animal Genetic Resources in Peasant Economies: The Case of the Box Keken Creole Pig in Yucatan

SUST 104.2001 R. SCARPA, P. KRISTJANSON, A. DRUCKER, M. RADENY, E.S.K. RUTO, and J.E.O. REGE: Valuing Indigenous Cattle Breeds in Kenya: An Empirical Comparison of Stated and Revealed Preference Value Estimates

SUST 105.2001 Clemens B.A. WOLLNY: The Need to Conserve Farm Animal Genetic Resources Through Community-Based Management in Africa: Should Policy Makers be Concerned?

SUST $\quad 106.2001$ J.T. KARUGIA, O.A. MWAI, R. KAITHO, Adam G. DRUCKER, C.B.A. WOLLNY and J.E.O. REGE: Economic Analysis of Crossbreeding Programmes in Sub-Saharan Africa: A Conceptual Framework and Kenyan Case $\underline{\text { Study }}$

SUST 107.2001 W. AYALEW, J.M. KING, E. BRUNS and B. RISCHKOWSKY: Economic Evaluation of Smallholder Subsistence Livestock Production: Lessons from an Ethiopian Goat Development Program 
108.2001 Gianni CICIA, Elisabetta D'ERCOLE and Davide MARINO: Valuing Farm Animal Genetic Resources by Means of Contingent Valuation and a Bio-Economic Model: The Case of the Pentro Horse

SUST

109.2001 Clem TISDELL: Socioeconomic Causes of Loss of Animal Genetic Diversity: Analysis and Assessment

SUST 110.2001 M.A. JABBAR and M.L. DIEDHOU: Does Breed Matter to Cattle Farmers and Buyers? Evidence from West $\underline{\text { Africa }}$

SUST $\quad 1.2002 \quad$ K. TANO, M.D. FAMINOW, M. KAMUANGA and B. SWALLOW: Using Conjoint Analysis to Estimate Farmers' Preferences for Cattle Traits in West Africa

ETA 2.2002 Efrem CASTELNUOVO and Paolo SURICO: What Does Monetary Policy Reveal about Central Bank's Preferences?

WAT 3.2002 Duncan KNOWLER and Edward BARBIER: The Economics of a "Mixed Blessing" Effect: A Case Study of the Black Sea

CLIM $\quad 4.2002$

VOL $\quad 5.2002$

CLIM 6.2002

Andreas LÖSCHEL: Technological Change in Economic Models of Environmental Policy: A Survey

Carlo CARRARO and Carmen MARCHIORI: Stable Coalitions

ETA $7.2002 \quad \begin{aligned} & \text { Comparison on European Gasoline Markets } \\ & \text { Effrosyni DIAMANTOUDI and Eftichios S. SARTZETAKIS: Stable International Environmental Agreements: An } \\ & \text { Analytical Approach }\end{aligned}$

KNOW 8.2002 Alain DESDOIGTS: Neoclassical Convergence Versus Technological Catch-up: A Contribution for Reaching a Consensus

NRM $\quad 9.2002 \quad$ Giuseppe DI VITA: Renewable Resources and Waste Recycling

KNOW 10.2002 Giorgio BRUNELLO: Is Training More Frequent when Wage Compression is Higher? Evidence from 11 European Countries

ETA 11.2002 Mordecai KURZ, Hehui JIN and Maurizio MOTOLESE: Endogenous Fluctuations and the Role of Monetary Policy

KNOW 12.2002 Reyer GERLAGH and Marjan W. HOFKES: Escaping Lock-in: The Scope for a Transition towards Sustainable Growth?

NRM 13.2002 Michele MORETTO and Paolo ROSATO: The Use of Common Property Resources: A Dynamic Model

CLIM 14.2002 Philippe QUIRION: Macroeconomic Effects of an Energy Saving Policy in the Public Sector

CLIM 15.2002 Roberto ROSON: Dynamic and Distributional Effects of Environmental Revenue Recycling Schemes: Simulations with a General Equilibrium Model of the Italian Economy

CLIM $16.2002 \quad$ Francesco RICCI (1): Environmental Policy Growth when Inputs are Differentiated in Pollution Intensity

ETA 17.2002 Alberto PETRUCCI: Devaluation (Levels versus Rates) and Balance of Payments in a Cash-in-Advance Economy

Coalition $\quad 18.200$

László Á. KÓCZY (liv): The Core in the Presence of Externalities

Theory

Network

Coalition 19.2002

Theory

Network

Coalition

Theory

Network

NRM

Steven J. BRAMS, Michael A. JONES and D. Marc KILGOUR (liv): Single-Peakedness and Disconnected Coalitions

20.2002

Guillaume HAERINGER (liv): On the Stability of Cooperation Structures

CLIM 22.2002

Fausto CAVALLARO and Luigi CIRAOLO: Economic and Environmental Sustainability: A Dynamic Approach in Insular Systems

CLIM 23.2002

Barbara BUCHNER, Carlo CARRARO, Igor CERSOSIMO and Carmen MARCHIORI: Back to Kyoto? US Participation and the Linkage between R\&D and Climate Cooperation

ETA 24.2002

Andreas LÖSCHEL and ZhongXIANG ZHANG: The Economic and Environmental Implications of the US Repudiation of the Kyoto Protocol and the Subsequent Deals in Bonn and Marrakech

CLIM 25.2002

Marzio GALEOTTI, Louis J. MACCINI and Fabio SCHIANTARELLI: Inventories, Employment and Hours

ETA 26.200

Hannes EGLI: Are Cross-Country Studies of the Environmental Kuznets Curve Misleading? New Evidence from Time Series Data for Germany

\section{SUST $\quad 27.2002$}

SUST 28.2002

Joseph C. COOPER and Giovanni SIGNORELLO: Farmer Premiums for the Voluntary Adoption of Conservation Plans

KNOW 29.2002

The ANSEA Network: Towards An Analytical Strategic Environmental Assessment

ETA $\quad 30.2002$

NRM $\quad 31.2002$

Geographic Concentration and Increasing Returns. a Survey of Evidence

Robert N. STAVINS: Lessons from the American Experiment with Market-Based Environmental Policies

NRM $\quad 32.2002$

the Catchment Scale: An Application to Diffuse Pollution Control in the Venice Lagoon

Robert N. STAVINS: National Environmental Policy During the Clinton Years

KNOW $\quad 33.2002$

A. SOUBEYRAN and H. STAHN : Do Investments in Specialized Knowledge Lead to Composite Good Industries?

KNOW $34.2002 \quad \overline{\text { G. BRUNELLO, M.L. PARISI and Daniela SONEDDA: Labor Taxes, Wage Setting and the Relative Wage }}$ $\underline{\text { Effect }}$

CLIM $35.2002 \quad$ C. BOEMARE and P. QUIRION (lv): Implementing Greenhouse Gas Trading in Europe: Lessons from Economic Theory and International Experiences 
CLIM

CLIM

CLIM

SUST

NRM

NRM

CLIM

CLIM

CLIM

ETA

ETA

SUST

SUST

KNOW

Coalition

Theory

Network

Coalition

Theory

Network

ETA

ETA

CLIM

ETA

SUST

SUST

SUST

SUST

VOL

ETA

PRIV

PRIV

PRIV

SUST

ETA

PRIV

CLIM

CLIM

SUST

SUST

NRM

PRIV

PRIV
36.2002

37.2002

38.2002

39.2002

40.2002

41.2002

42.2002

43.2002

44.2002

45.2002

46.2002

47.2002

48.2002

49.2002

50.2002

51.2002

52.2002

53.2002

54.2002

55.2002

56.2002

57.2002

58.2002

59.2002

60.2002

61.2002

62.2002

63.2002

64.2002

65.2002

66.2002

67.2002

68.2002

69.2002

70.2002

71.2002

72.2002

73.2002

74.2002

T.TIETENBERG (lv): The Tradable Permits Approach to Protecting the Commons: What Have We Learned? K. REHDANZ and R.J.S. TOL (lv): On National and International Trade in Greenhouse Gas Emission Permits C. FISCHER (lv): Multinational Taxation and International Emissions Trading

G. SIGNORELLO and G. PAPPALARDO: Farm Animal Biodiversity Conservation Activities in Europe under the Framework of Agenda 2000

S.M. CAVANAGH, W. M. HANEMANN and R. N. STAVINS: Muffled Price Signals: Household Water Demand under Increasing-Block Prices

A. J. PLANTINGA, R. N. LUBOWSKI and R. N. STAVINS: The Effects of Potential Land Development on Agricultural Land Prices

C. OHL (lvi): Inducing Environmental Co-operation by the Design of Emission Permits

J. EYCKMANS, D. VAN REGEMORTER and V. VAN STEENBERGHE (lvi): Is Kyoto Fatally Flawed? An Analysis with MacGEM

A. ANTOCI and S. BORGHESI (lvi): Working Too Much in a Polluted World: A North-South Evolutionary Model

P. G. FREDRIKSSON, Johan A. LIST and Daniel MILLIMET (lvi): $\underline{\text { Chasing the Smokestack: Strategic }}$

Policymaking with Multiple Instruments

Z. YU (lvi): A Theory of Strategic Vertical DFI and the Missing Pollution-Haven Effect

Y. H. FARZIN: Can an Exhaustible Resource Economy Be Sustainable?

Y. H. FARZIN: Sustainability and Hamiltonian Value

C. PIGA and M. VIVARELLI: Cooperation in R\&D and Sample Selection

M. SERTEL and A. SLINKO (liv): Ranking Committees, Words or Multisets

Sergio CURRARINI (liv): Stable Organizations with Externalities

Robert N. STAVINS: Experience with Market-Based Policy Instruments

C.C. JAEGER, M. LEIMBACH, C. CARRARO, K. HASSELMANN, J.C. HOURCADE, A. KEELER and

R. KLEIN (liii): Integrated Assessment Modeling: Modules for Cooperation

Scott BARRETT (liii): Towards a Better Climate Treaty

Richard G. NEWELL and Robert N. STAVINS: Cost Heterogeneity and the Potential Savings from Market-

Based Policies

Paolo ROSATO and Edi DEFRANCESCO: Individual Travel Cost Method and Flow Fixed Costs

Vladimir KOTOV and Elena NIKITINA (lvii): Reorganisation of Environmental Policy in Russia: The Decade of Success and Failures in Implementation of Perspective Quests

Vladimir KOTOV (lvii): Policy in Transition: New Framework for Russia's Climate Policy

Fanny MISSFELDT and Arturo VILLAVICENCO (lvii): How Can Economies in Transition Pursue Emissions Trading or Joint Implementation?

Giovanni DI BARTOLOMEO, Jacob ENGWERDA, Joseph PLASMANS and Bas VAN AARLE: $\underline{\text { Staying Together }}$ or Breaking Apart: Policy-Makers' Endogenous Coalitions Formation in the European Economic and Monetary $\underline{\text { Union }}$

Terms: Dynamic Efficiency Plus Intergenerational Equity

Carlo CAPUANO: Demand Growth, Entry and Collusion Sustainability

Tobin's Q

Federico MUNARI and Maurizio SOBRERO: The Effects of Privatization on R\&D Investments and Patent Productivity

Orley ASHENFELTER and Michael GREENSTONE: Using Mandated Speed Limits to Measure the Value of a Statistical Life

Paolo SURICO: US Monetary Policy Rules: the Case for Asymmetric Preferences

Rinaldo BRAU and Massimo FLORIO: Privatisations as Price Reforms: Evaluating Consumers' Welfare Changes in the U.K.

Barbara K. BUCHNER and Roberto ROSON: Conflicting Perspectives in Trade and Environmental Negotiations Philippe QUIRION: Complying with the Kyoto Protocol under Uncertainty: Taxes or Tradable Permits?

Anna ALBERINI, Patrizia RIGANTI and Alberto LONGO: Can People Value the Aesthetic and Use Services of Urban Sites? Evidence from a Survey of Belfast Residents

Marco PERCOCO: Discounting Environmental Effects in Project Appraisal

Philippe BONTEMS and Pascal FAVARD: Input Use and Capacity Constraint under Uncertainty: The Case of $\underline{\text { Irrigation }}$

Mohammed OMRAN: The Performance of State-Owned Enterprises and Newly Privatized Firms: Empirical Evidence from Egypt

74.2002 Mike BURKART, Fausto PANUNZI and Andrei SHLEIFER: Family Firms 
(xlii) This paper was presented at the International Workshop on "Climate Change and Mediterranean Coastal Systems: Regional Scenarios and Vulnerability Assessment" organised by the Fondazione Eni Enrico Mattei in co-operation with the Istituto Veneto di Scienze, Lettere ed Arti, Venice, December 9-10, 1999.

(xliii)This paper was presented at the International Workshop on "Voluntary Approaches, Competition and Competitiveness" organised by the Fondazione Eni Enrico Mattei within the research activities of the CAVA Network, Milan, May 25-26,2000.

(xliv) This paper was presented at the International Workshop on "Green National Accounting in Europe: Comparison of Methods and Experiences" organised by the Fondazione Eni Enrico Mattei within the Concerted Action of Environmental Valuation in Europe (EVE), Milan, March 4-7, 2000

(xlv) This paper was presented at the International Workshop on "New Ports and Urban and Regional Development. The Dynamics of Sustainability" organised by the Fondazione Eni Enrico Mattei, Venice, May 5-6, 2000.

(xlvi) This paper was presented at the Sixth Meeting of the Coalition Theory Network organised by the Fondazione Eni Enrico Mattei and the CORE, Université Catholique de Louvain, Louvain-laNeuve, Belgium, January 26-27, 2001

(xlvii) This paper was presented at the RICAMARE Workshop "Socioeconomic Assessments of Climate Change in the Mediterranean: Impact, Adaptation and Mitigation Co-benefits", organised by the Fondazione Eni Enrico Mattei, Milan, February 9-10, 2001

(xlviii) This paper was presented at the International Workshop "Trade and the Environment in the Perspective of the EU Enlargement ", organised by the Fondazione Eni Enrico Mattei, Milan, May $17-18,2001$

(xlix) This paper was presented at the International Conference "Knowledge as an Economic Good", organised by Fondazione Eni Enrico Mattei and The Beijer International Institute of Environmental Economics, Palermo, April 20-21, 2001

(1) This paper was presented at the Workshop "Growth, Environmental Policies and

Sustainability” organised by the Fondazione Eni Enrico Mattei, Venice, June 1, 2001

(li) This paper was presented at the Fourth Toulouse Conference on Environment and Resource Economics on "Property Rights, Institutions and Management of Environmental and Natural Resources", organised by Fondazione Eni Enrico Mattei, IDEI and INRA and sponsored by MATE, Toulouse, May 3-4, 2001

(lii) This paper was presented at the International Conference on "Economic Valuation of Environmental Goods", organised by Fondazione Eni Enrico Mattei in cooperation with CORILA, Venice, May 11, 2001

(liii) This paper was circulated at the International Conference on "Climate Policy - Do We Need a New Approach?", jointly organised by Fondazione Eni Enrico Mattei, Stanford University and Venice International University, Isola di San Servolo, Venice, September 6-8, 2001

(liv) This paper was presented at the Seventh Meeting of the Coalition Theory Network organised by the Fondazione Eni Enrico Mattei and the CORE, Université Catholique de Louvain, Venice, Italy, January 11-12, 2002

(lv) This paper was presented at the First Workshop of the Concerted Action on Tradable Emission Permits (CATEP) organised by the Fondazione Eni Enrico Mattei, Venice, Italy, December 3-4, 2001

(lvi) This paper was presented at the ESF EURESCO Conference on Environmental Policy in a Global Economy "The International Dimension of Environmental Policy", organised with the collaboration of the Fondazione Eni Enrico Mattei , Acquafredda di Maratea, October 6-11, 2001

(lvii) This paper was presented at the First Workshop of "CFEWE - Carbon Flows between Eastern and Western Europe", organised by the Fondazione Eni Enrico Mattei and Zentrum fur Europaische Integrationsforschung (ZEI), Milan, July 5-6, 2001 


\section{SERIES}

CLIM Climate Change Modelling and Policy (Editor: Marzio Galeotti)

NRM Natural Resources Management (Editor: Carlo Giupponi)

SUST Sustainability Indicators and Environmental Evaluation (Editor: Carlo Carraro)

KNOW Knowledge, Technology, Human Capital (Editor: Dino Pinelli)

PRIV Privatisation, Regulation, Antitrust (Editor: Bernardo Bortolotti)

MGMT Corporate Sustainable Management (Editor: Andrea Marsanich)

ETA Economic Theory and Applications (Editor: Carlo Carraro) 